\title{
Title: On the nature of the earliest known lifeforms
}

Dheeraj Kanaparthi ${ }^{1,2 \& 3^{*}}$, Marko Lampe ${ }^{4}$, Baoli Zhu ${ }^{2 \& 5}$, Thomas Boesen ${ }^{6}$, Andreas Klingl ${ }^{7}$, Petra Schwille ${ }^{1} \&$ Tillmann Lueders ${ }^{2 \& 3^{*}}$

5

\section{Affiliations:}

${ }^{1}$ Max-Planck Institute for Biochemistry, Munich, Germany

${ }^{2}$ Chair of Ecological Microbiology, BayCeer, University of Bayreuth, Germany.

$10 \quad{ }^{3}$ Helmholtz Zentrum Munich, Germany

${ }^{4}$ Advanced Light Microscopy Facility, European Molecular Biology Laboratory, Heidelberg, Germany.

${ }^{5}$ Key Laboratory of Agro-ecological Processes in Subtropical Regions,

Taoyuan Agroecosystem Research Station, Institute of Subtropical

15 Agriculture, Chinese Academy of Sciences, Changsha, China.

${ }^{6}$ Department of Biosciences, Center for Electromicrobiology, Aarhus, Denmark.

${ }^{7}$ Department of Biology, LMU, Planegg-Martinsried, Germany.

*Corresponding authors

Lead contact: kanaparthi@biochem.mpg.de

\begin{abstract}
:
Archaean Eon microfossils were known to have the most complex of prokaryotic morphologies. Given the morphology of an organism is governed by information encoded in its genome, it was proposed that these primitive organisms most likely possessed molecular biological processes. Here we worked with bacterial protoplasts, incapable of regulating either their morphology or reproductive processes. We then exposed these cells to environmental conditions of Archaean Earth to understand if cytological complexity of microfossils is a result of biological or ecological factors. As we reproduced the morphologies of all known Archean microfossils, we propose that complex morphologies of
\end{abstract}


these microfossils could be explained not by presence but by complete absence of molecular biological mechanisms. Environmental conditions and architecture of the cell membrane are the only factors that determined the morphology of these organisms. Based on our observations we argue against the use of morphology in systemic paleontology and present a case for reinterpretation of Archaean microfossils as liposome like protocells.

One Sentence Summary: Microfossils reported from Archaean BIF's most likely were liposome like protocells, which had evolved mechanisms for energy conservation, but not for regulating cell morphology and replication.

Main Text: Pilbara iron formation (PIF), Western Australia (1) and Barberton greenstone belt (BGB)(2), South Africa are the oldest known rock formations, which haven't been subjected to significant metamorphic alterations $(1,2)$. Hence, these rock formations have been a subject of numerous scientific investigations that were focused on understanding 15 biology and biogeochemistry of Archaean Earth (1-6). These studies led to the discovery of organic structures within these rock formations, that resemble microorganisms in their morphology with $\delta^{13} \mathrm{C}$ composition consistent with biologically derived organic carbon $(5,7)$. Although these observations suggest that these structures were fossil remnants of Archaean microorganisms, any such interpretation along with their physiology and biological origin has been a serious point of contention among researcher (8-12). Two factors currently limit wider acceptance of their biological origin - absence of truly analogous microfossil morphologies among extant prokaryotes and absence of an indication for a distinctively biological process like cell-division among these microfossils (except for Swartkopie formations) (6). Decades of back and forth arguments led to general consensus, that reconstructing the lifecycles of 
Archaean Eon organisms, however improbable it appeared to be, is the only way of understanding the nature of these microfossils (13).

In our previous work we demonstrated a method of reproduction that was entirely mediated

5 by physiochemical properties of the cell constituents without the intervention of molecular biological processes. Given such primitive cells could have existed on early Earth, prior to the origin of prokaryotes, we propose the possibility that primordial cells should have reproduced by these processes. In the present work we test this hypothesis. Here we compare the morphologies of cells from our previous study with the oldest of all known microfossils.

A Gram-positive (Exiguobacterium Strain-Molly) and a Gram-negative (Rhodobacter sphaeroides) bacteria were transformed into their protoplast state (EM-P and $R S-P$ respectively). A state in which cells are devoid of molecular biological processes regulating either their morphology or reproductive processes. The procedure of such transformation is described in the methods section of the manuscript. We then grew these cells under presumed environmental conditions of Archaean Eon Earth (14). The exact environmental conditions of Archaean Earth nor the salt composition of its oceans is currently unknown. Nevertheless, recent studies demonstrated the Archaean Eon Earth's surface temperatures ranged between $26^{\circ}$ to $35^{\circ} \mathrm{C}(15,16)$ and its oceans are hypothesized to be $1.5-2$ times saltier than the

20 current ones (14). To replicate these conditions, we grew both $E M-P$ and $R S-P$ under static conditions at $30^{\circ} \mathrm{C}$ in half-strength tryptic soya broth and nutrient broth amended with $5-10 \%$ Dead Sea salt (DSS) respectively. We imaged these cells at regular intervals to understand if or how these cells grew and reproduced under these conditions. Subsequently we compared morphologies of EM-P and $R S-P$ observed in our incubations with Achaean microfossils

25 (3800-2500 million years old). As physio-chemical mechanisms behind complex 
morphologies is explained in the accompanying manuscript $(17,18)$, we restrict the scope of current manuscript to drawing parallels between bacteria from our study and Archaean microfossils, in-terms of their morphologies, elemental, and carbon isotopic composition.

5 In the first two sections of the manuscript, we present such an in-depth morphological comparison. In the later section, we present our case for reinterpretation of these microfossils as proto-Gram-positive and proto-Gram-negative bacteria.

\section{Morphological similarities between 3.5 - 2.4-billion-year-old spherical microfossils with}

Spherical microfossils of different morphologies were discovered from sites within PIF (1, $19,20)$ and $\mathrm{BGB}(4,6,21)$. All these microfossils resemble $E M-P$ reproducing either via formation of internal or external daughter cells.

The first step in reproduction by forming intracellular daughter cells is the formation of hollow intracellular vesicles (ICV's) (Fig. 1E\&F S\& fig. S1). Over time, size and number of ICV's within a cell gradually increased (Fig. 1E\&F and fig. S1). EM-P with such ICV's, resemble microfossils reported from Apex chert (1) (Fig. 1 \& S2). Like the Apex-chert microfossils, intracellular vesicles of $E M-P$ were hollow and presence of organic carbon (cytoplasm) in these cells was restricted to spaces in-between ICV's (Fig. 1A-F). Microfossils reported from other sites like Strelley Pool Formation (SPF) formations (22) (Fig. 1G \& fig. S3-S5), Farrel Quarzite (23)(fig. S6), Turee creek (24)(fig. S7), Fig tree (3)(fig. S8), and Hooggenoeg formations (21)(fig. S9), likely are morphological variants of EM-P and Apex- 

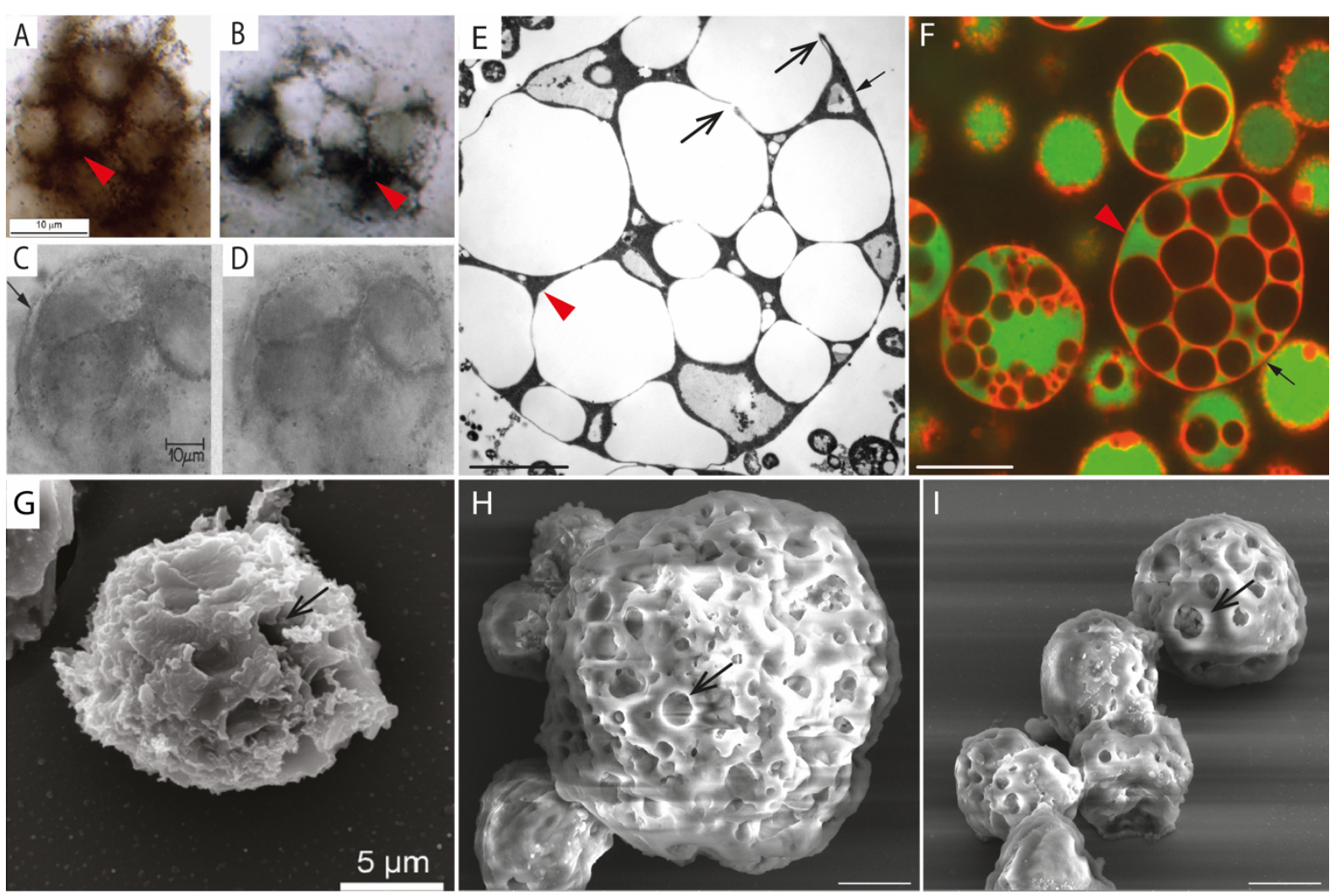

Fig 1. Morphological comparison of Apex chert \& SPF microfossils with EM-P.

Images A-D are spherical microfossils reported from Apex chert (originally published by Schopf et al., 1987) (25). Images E \& F are TEM and confocal images of morphologically analogous $E M-P$ cells. Cells in image $\mathrm{F}$ were stained with universal membrane stain, $\mathrm{FM}^{\mathrm{TM}}$ 595 (red) and DNA stain, PicoGreen (green). Red arrows in images A-F points to cytoplasm sandwiched in-between large hollow vesicles. Black arrows (closed) in images C\&F points to appearance of duel outer membrane due to the presence of ICV's (fig. S3). Open arrows point to ruptures in vesicle membrane, which led to formation of polygonal depressions on cell surface (H\&I). Image G show microfossil reported from SPF site (originally published by Delarue et al., 2020) (22). Images H \& I are SEM images of morphologically analogous EM$P$ cells. Arrows in images G-I points to depressions formed on cell surface due to rupture of vesicle membrane (fig. S5-S6). Scale bars: $0.5 \mu \mathrm{m}(\mathrm{E}), 5 \mu \mathrm{m}(\mathrm{F})$ and $1 \mu \mathrm{m}(\mathrm{H} \& \mathrm{I})$. 
chert microfossils. For instance, EM-P with a large number of relatively smaller ICV's resemble microfossils reported from Fig tree microfossils, both in size and shape (fig. S8). On the other hand, EM-P with a relatively larger number of ICV's squeezed within the cell, resemble SPF, Farrel quarzite and Turee creek microfossils with polygonal alveolar structures

5 (22)(Fig. 1G-I \& S5-S7). Given the uncanny morphological resemblance between $E M-P$ and SPF microfossils (fig. S3-S5), we presume that polygonal surface depressions could have formed by rupture of individual vesicles below the cell surface, similar to what was observed in $E M-P$ (Fig. 1D-I \& S5) (22)

10 The second stage of reproduction involves formation of daughter cells (fig. S1 D-H). Daughter cells were formed by blebbing of vesicle membrane (fig. 3 in reference 18), leading to formation of either individual or a string of daughter cells (fig. 3 in reference 18). Based on number of ICV's, two cell morphologies were observed. Cells with a single large (fig. S1E) or multiple smaller ICV's (fig. S1E). Gradual transfer of cytoplasm from parent to daughter cells led to a gradual reduction of cytoplasmic volume of the cell and a corresponding increase in vesicle size and number of daughter cell, within the ICV's (fig. S3 in reference 18). Over time, we noticed cells with a single large hollow ICV with tiny daughter cells (fig. S10-S12). Morphology of these cells resemble microfossils reported from SPF (fig. S10. S11 \& S13) $(26,27)$ and Goldsworth formation (fig. S12)(28). In case of cells with a multiple

20 ICV's, cells underwent lysis to release ICV's with daughter cells (Movie S1-3 \& fig. S13DF). During the early logarithmic growth phase (at low cell densities), these ICV's aggregations gradually got separated from one another (fig. S13). Microfossils reported from SPF (19, 27)(fig. S13-S15), Turee creek (fig. S16)(24) and Goldsworth formations (13, 28)(fig. $2 \&$ S17) bare close morphological similarities with the all the intermediate morphotypes of EM-P undergoing cell lysis, release and dispersion of ICV's. 

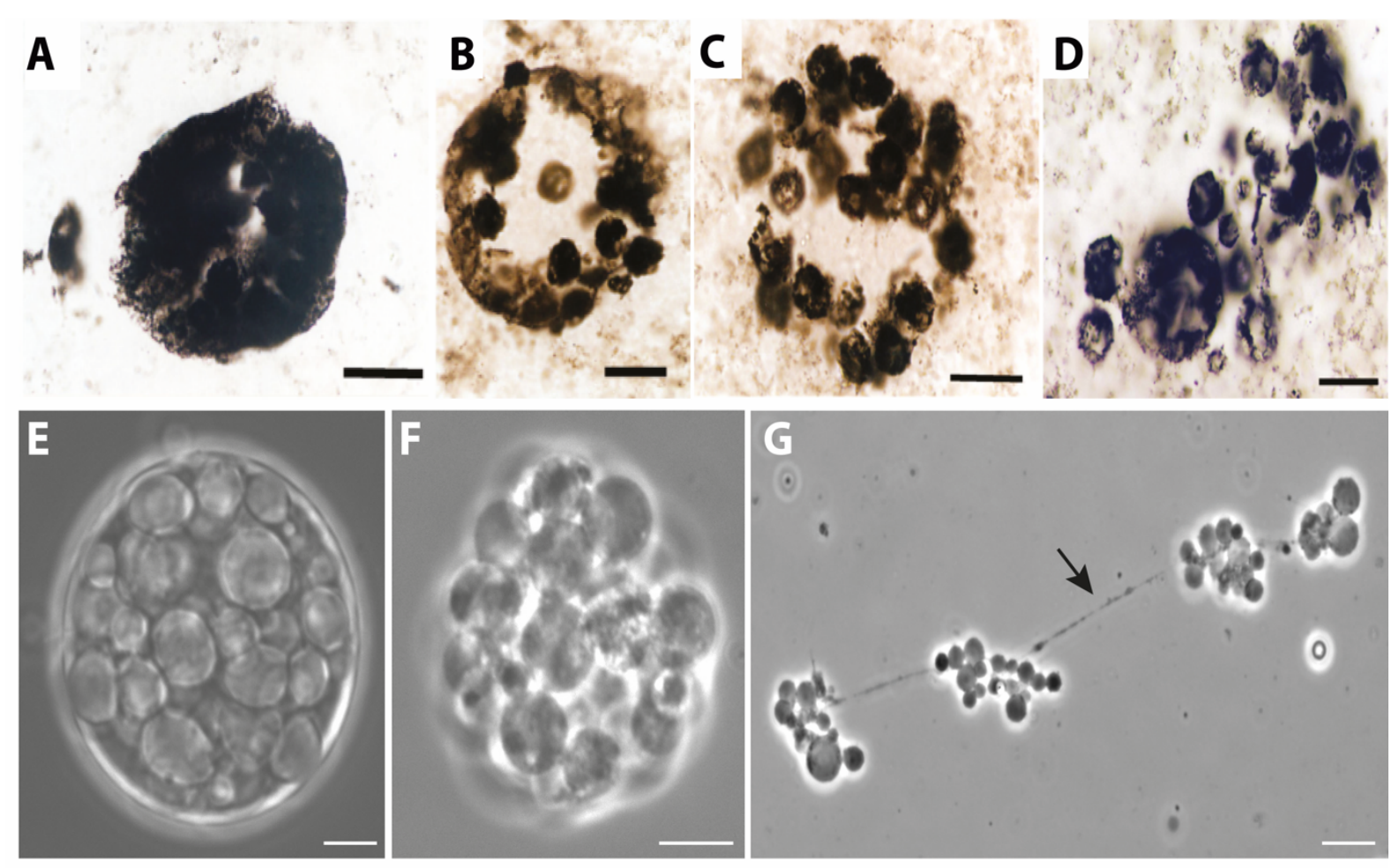

Fig 2. Morphological comparison between Goldsworth microfossils and EM-P.

Images A-D shows spherical microfossils reported from Goldsworth formation (originally published by Sugitani et al., 2009) (13). Images E-G are images of $E M-P$ cell undergoing

5 lysis (E) and dispersion (F) of intracellular vacuoles. Arrows in these images points to interlinks between the released vesicles. Scale bars: $20 \mu \mathrm{m}$ (A) $2 \mu \mathrm{m}(\mathrm{E} \& \mathrm{~F})$ and $5 \mu \mathrm{m}(\mathrm{G})$.

During the late logarithmic growth phase (at high cell densities), expelled vesicles did not undergo subsequent dispersion (fig. S18). These vesicles remained as aggregates and formed

10 mat like structures at the bottom of the culture bottles (fig. S18-20). Moreover, gradual compression of vesicle, led to transformation of spherical vesicles into polygonal shapes, leading to the formation of honeycomb shaped mats (fig. S18-25). Organic structures resembling both the above discussed morphologies were reported from several microfossil sites. Large aggregations of spherical cells devoid of internal organic carbon reported from

15 North-Pole formation (NPF) (fig. S20)(20) bare remarkably close resemblance to the above described morphotypes of $E M-P$. Like observed in $E M-P$, distribution of organic carbon in 
NPF restricted to periphery of the spherical cells (fig. S20). Along with the morphological and organizational similarities with NPF microfossils, EM-P also exhibited all the accessory structures observed in NPF formations like the filamentous structures originating from the spherical cells and clots of organic carbon (fig. S20D). We presume that filamentous

5 structures could have formed during the release of ICV's, like observed in EM-P (Movie S3). Large clots of organic carbon should have been the membrane debris that was formed during the process of lysis, that led to the release of ICV's (fig. S20D and Movie S3). Honeycomb shaped mats formed by $E M-P$ bare uncanny morphological resemblance with organic structures reported from Nuga, BRC, Mt. Grant, SPF and Turee creek formations (fig. S20$\mathrm{S} 25)(24,29-32)$.

In the last growth stage, vacuole membrane underwent rupture to release of daughter cells (Movie S4 \& fig. S11). We observed formation of three distinct types of daughter cells individual spherical daughter cells (Movie S4 \& fig. S11), string of daughter cells (fig. S26) and daughter cells that were still attached to the membrane debris of parent cell (Movie S5, fig. S27 \& S28). All these daughter cell morphotypes were reported from microfossil sites like - SPF (fig. S12), Moodies, Mt. Grant and Sulphur spring formations (fig. S26-S28)(3234). Lysis and release of either ICV's or daughter cells led to collapse or deflation of large spherical cell or Vesicles (Movie S4 \& fig. S29C-E). Such deflated cells were often observed 20 during the late-growth stages of $E M-P$ and bare morphological resemblance with Kromberg formation microfossils (fig. S29)(35).

The second method of reproduction observed in EM-P is by formation of external daughter cells (18). Cells reproducing by this process bares morphological resemblance to microfossils reported from Swartkopie (6), Cleverville (36) and Sheba formations (37) along with rest of 
the spherical microfossils from above discussed sites like NPF and Sulphur spring formations (fig. S30-S35) (20, 38). First stage in such a mode of reproduction involves formation of a bud like structure out of the cell (fig. S30C-F), which resemble NPF microfossils with pustular protuberances (20) (fig. S30). Subsequently, these buds either grew in size and

5 detached from the parent cell (18) or they transformed gradually into a string of daughter cells (fig. S33-S35). All cellular morphotypes observed in former type of reproduction (fig. S31 L-R) like, individual spherical cells, hourglass shaped cells undergoing fission and cells in dyads, all bares close morphological similarities with microfossils reported from Swartkopie formations (6) (fig. S31). In subsequent growth stages, we observed cells that were separated from one another with remnants of this process like membrane overhangs that resemble microfossils reported from Sheba formations (fig. S32)(37).

In addition to above discussed "binary division-like" cell replication, in some cases protuberances grew into string of daughter cell. $E M-P$ during this growth stage resemble microfossils reported from Cleverville (36)(fig. S33) and Sulphur spring formations (fig. S34 \& S35)(38). Based on the morphological similarities, we propose that hollow spherules arranged in a zig-zag manner reported from Onverwacht (Fig. 3)(21), spherical cells attached to one another resembling a beaded string that were reported from Mount Grant and Moodies (fig. S26)(33) could also have formed by $E M-P$ like cells fossilized at different stages of their reproduction.

Most microfossils from PIF and BGB were discovered within parallel layers of organic carbon, termed laminations $(30,39-41)$. In-case of spherical microfossils, they were almost always discovered in close association with such laminations (19). During the late growth stages, $E M-P$ formed very similar structures. These structures were formed by a three- 
step process. First, EM-P grew as multiple layers of cells (fig. S36). Second, lysis of these
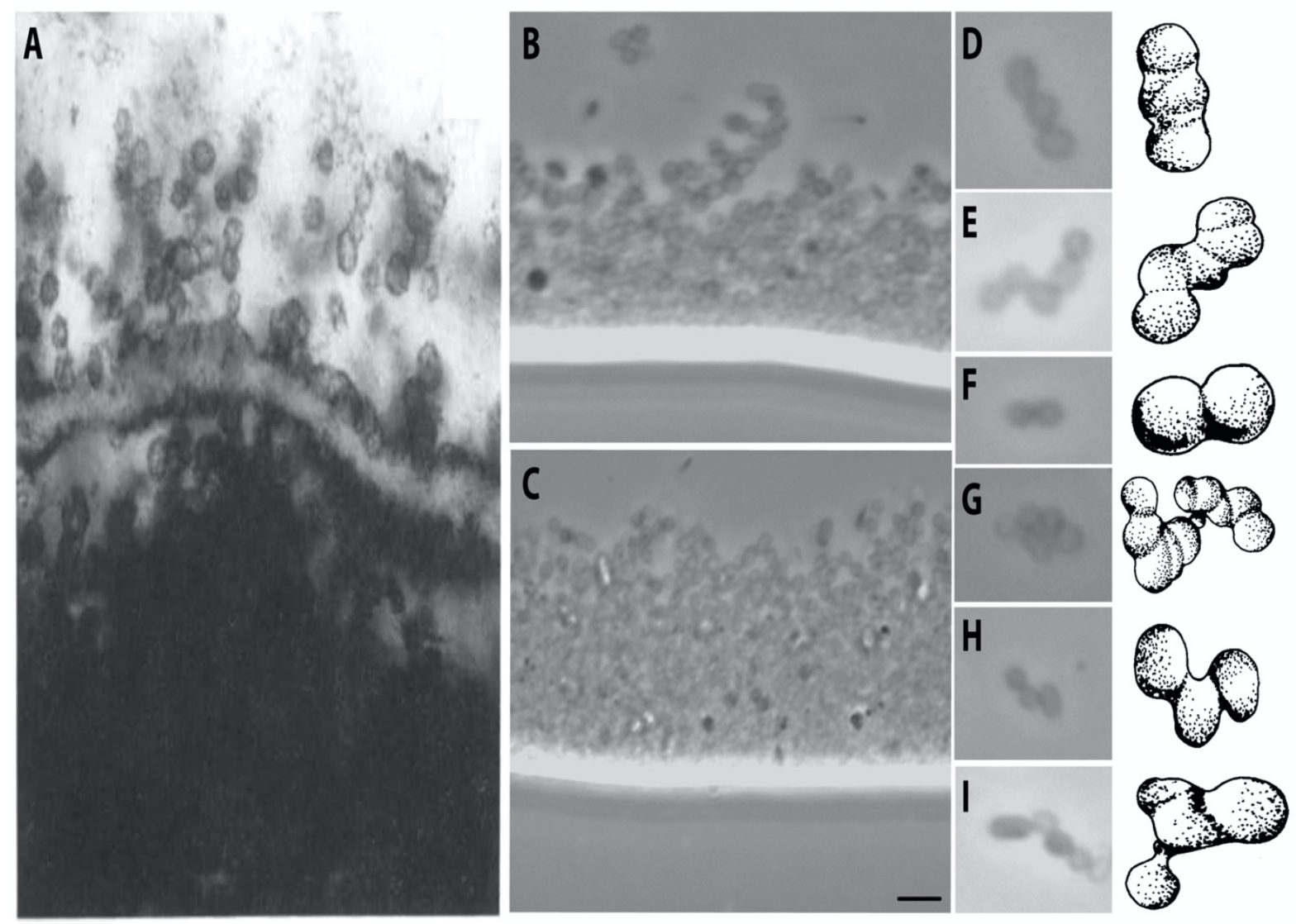

Fig 3. Comparison of Onverwacht group microfossils with EM-P.

5 Image A shows Onverwacht microfossils (5)(originally published by Walsh et al., 1992).

Images $\mathrm{C} \& \mathrm{D}$ show sub micrometer size cells $E M-P$, exhibiting morphological similarities with Onverwacht microfossils. Images D-I show cluster of $E M-P$ cells organized in different configurations along with interpretive drawings of morphologically similar Onverwacht microfossil (originally published by Westall et al., 2001)(21). Scale bars: $5 \mu \mathrm{m}(\mathrm{C}$, also applies to images B \& D-I).

cells led to the formation of considerable amount of membrane debris (fig. S19 \& S37). In the third step, membrane debris coalesced to form large fabric like structures, slightly differing in their morphology (fig. S38-61). Morphologically similar fabric-like structures were reported 
from several microfossil sites (fig. S38-61) (12, 19, 22, 23, 32, 42-44). Over time these structures grew in area to form a continuous layer of membrane enclosing large cell population of cells, resembling different types of laminated structures reported from microfossil sites (30) (Fig. 4, S43-54, Movie S6).

5

All distinctive features of such lamination like raised mounds, swirls (fig. S58 \& S59) (41, 45), bifurcating layers and lenticular gaps (Fig. 4, fig. S52, 48-51 \& Movie S6\&7) (30) were all observed in batch cultures of $E M-P$. Based on our observations, we propose that lenticular gaps within otherwise uniformly parallel laminations were formed due to un-uniform lysis or incomplete deflation of cells within individual layers of $E M-P$ cells (Fig. 4 \& fig. S50-52). In support of this proposition, we noticed these lenticular gaps consisted of an intact $E M-P$ cells that didn't underwent complete lysis or remnants of lysed cells within these gaps (Fig. 4 \& fig. S48\&49). Subsequent lysis of cells within these lenticular structures should have led to formation of hollow gaps, like the ones reported from Moodies formations (45)(fig. S50\&S51).

\section{Morphological similarities between 3.8-3-billion-year-old filamentous microfossils with protoplasts of Gram-negative bacteria}

20 Filamentous microfossils enclosed within clasts of organic carbon were reported from both PIF $(1,46,47)$ and BGB sites $(4,5)$. On the basis of their morphology and discovery site, these microfossils were classified into different taxonomic groups (1). For instance, filamentous microfossils from Apex chert alone are classified into 11 different phylogenetic groups (1). $R S$ - $P$ alone exhibited uncanny morphological similarity with all these microfossils 

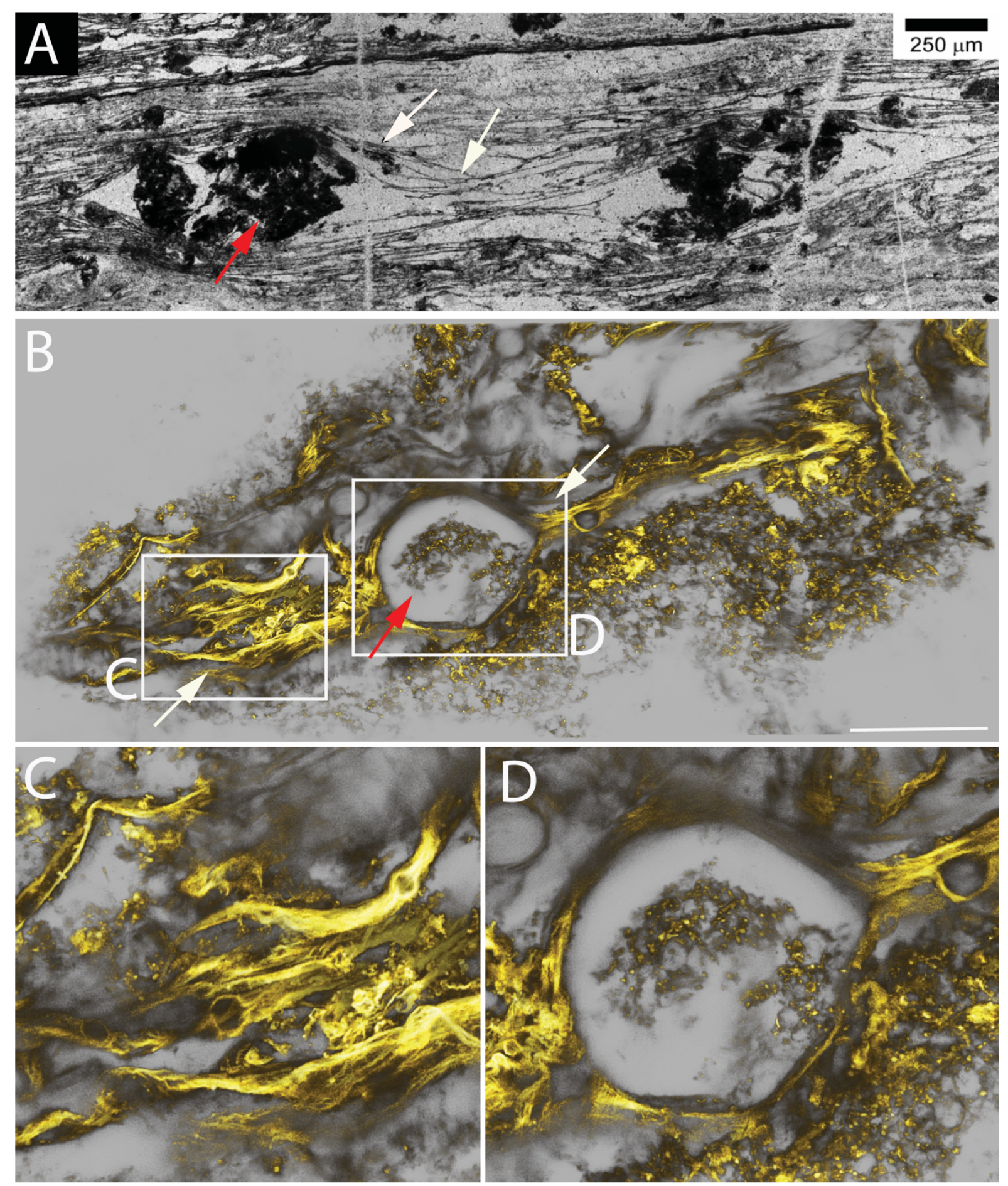

Fig 4. Morphological comparison of BRC laminations with EM-P's membrane debris.

Image A shows $\alpha$-type laminations reported from BRC (originally published by Tice et al.,

5 2009) (30). Images B-D is a 3D-rendered STED microscope image of EM-P's membrane debris exhibiting similar lenticular gaps. White arrows in both the images points to individual 
layers within the laminations. Red arrows point to the organic structures within the lenticular gaps (cells in image B). Images C \& D are magnified regions of image B, highlighting the multi-layered nature of membrane debris and presence of EM-P cell aggregations within the lenticular gaps. Scale bar: $20 \mu \mathrm{m}(\mathrm{B})$.

these microfossils that formed the basis for their phylogenetic segregation, like the hollow spherical vacuoles in case of Primaevifilum amoenum (fig. S62-65), comparatively thinner filaments exhibiting a banded pattern in case of Eoleptonema apex (Fig. 5H\&G) and even thinner filaments with rounded ends and sparsely distributed organic carbon in case of Archaeotrichion septatum (Fig. 5A-F), all represent different stages within the life cycle of $R S-P$ like cells (17). Morphological comparison of $R S-P$ with other filamentous Apex chert microfossils (1) and similar microfossils reported from North-pole (46) and Sulphur springs (48) is presented as fig. S62-S70.

15 SPF filamentous microfossils were among the well-studied in terms of their morphology, elemental and isotope composition (28). Two types of filamentous morphotypes were reported from this site - thin filamentous and thick tubular microfossils with scantly distributed organic matter (19). The description of thin thread like microfossils with clots of organic carbon (blistered appearance) resemble morphotypes of $R S$ - $P$ observed during early

20 stages of growth (fig. S73). $R S$ - $P$ morphotypes that were similar to tubular SPF microfossils were most frequently observed after 7 days of incubation (fig. S74). All distinctive morphological features of these microfossils like presence of spherical inclusions within tubular cells (fig. S72, Movie S8), characteristic twisting and bending of these filaments, were also exhibited by $R S-P$ (fig. S72-S74)(19). Such intracellular spherical inclusions in $R S$ - 
S8). Spherical structures with and devoid of internal organic carbon were observed in close proximity to the tubular SPF microfossils (fig. S74). Similar spherical structures were also observed in batch cultures of $R S-P$ (discussed in-detail in sections below) (fig. S72, red arrows).

5

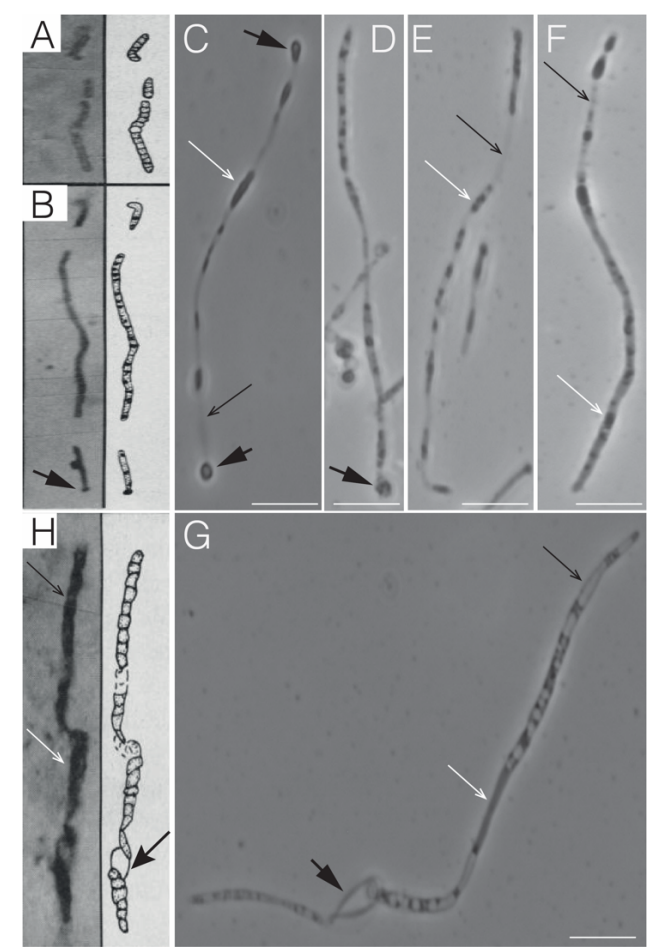

Fig 5. Morphological comparison of $A$. septatum and $E$. apex with $R S-P$.

Images A, B and $\mathrm{H}$ are A.septatum and E.apex respectively (originally published by Schopf et al., 1993) (1). Images C-F and G show $R S-P$ cells that are morphologically analogous to $A$.

septatum and E. apex. The distinctive features of $A$. septatum like thin filamentous cells with a banding pattern (mostly hollow with intermittently distributed organic carbon) (A \& B) and rounded ends (B-black arrow) were also exhibited by $R S-P$ (rounded ends indicated by black arrows in $\mathrm{C} \& \mathrm{D}$ and hollow filament in $\mathrm{C} \& \mathrm{D})$. Image $\mathrm{G}$ is filamentous cells of $R S-P$ exhibiting morphological similarity with E. apex. The black and white arrows in $\mathrm{G}$ and $\mathrm{H}$ points to regions for the filament with and without organic carbon. Closed black arrow points to characteristic twisting of hollow regions of cells. Scale bar: $5 \mu \mathrm{m}(\mathrm{C}-\mathrm{F} \& \mathrm{G})$. 
One of the morphologically distinct group of microfossils reported from both BGB and PIF are the lenticular microfossils $(4,5,19,28) . R S$ - $P$ exhibited morphologies that were very similar to all known lenticular microfossils - individual lenticular cells (Fig. 6\&7), chain-like

5 structures composed of lenticular cells (Fig. 7G \& fig. S75) and lenticular cells with internal voids (Fig. 6B-G \& fig. S75). These lenticular structures of $R S-P$ were formed by swelling of blister-like structures within filamentous cells, discussed above (fig. S71E-F). Lenticular microfossils reported from Overwacht formations (5), like the cells with a defined cell boundary and dense interior with organic carbon resemble an early growth-stage $R S-P$ cells (Fig. 6). In-comparison, microfossils reported from SPF having a fussy cell boundary and reticulate interiors resemble late growth-stage $R S$ - $P$ cells (Fig. 7) (32).
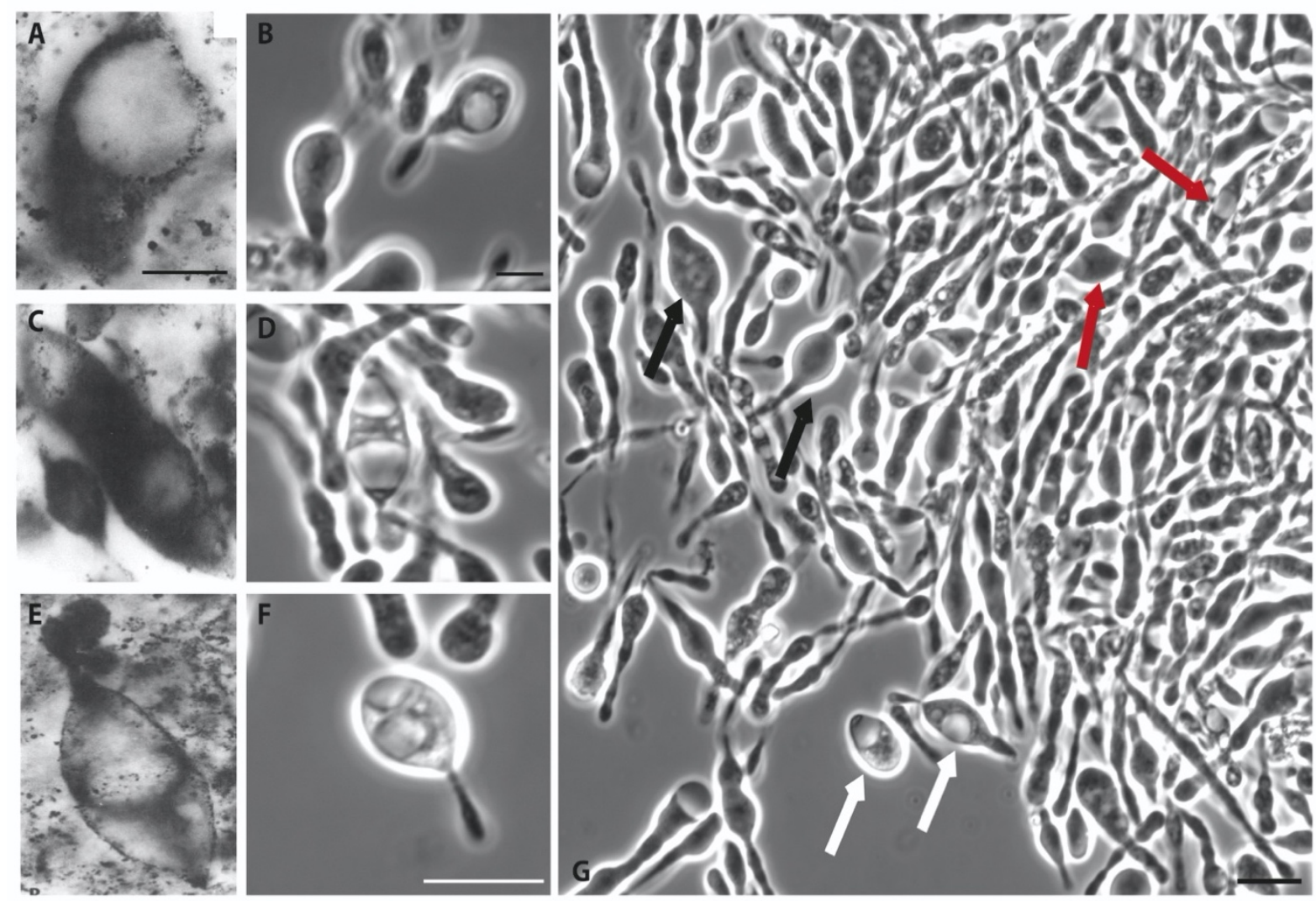

Fig 6. Comparison of Overwacht lenticular microfossils with $R S-P$. 
Images A, C \& E are lenticular microfossils reported from Overwacht region (originally published by Walsh et al., 1992) (5). Images $\mathrm{B}, \mathrm{D}, \mathrm{F} \& \mathrm{G}$ are images of $R S-P$. A\&B shows lenticular Overwacht and $R S-P$ cells exhibiting one vacuole. C\&D shows lenticular Overwacht and $R S-P$ cells exhibiting two terminal vacuoles. E\&F shows lenticular

5 Overwacht and $R S-P$ cells exhibiting three vacuoles. Image G phase-contrast image of threeday old $R S-P$ showing cells of different lenticular morphologies. Scale bar: $10 \mu \mathrm{m}$ (A, C \& E), $2 \mu \mathrm{m}(\mathrm{B}, \mathrm{D} \& \mathrm{~F})$ and $10 \mu \mathrm{m}(\mathrm{G})$.

A recent study reported microfossils from Nuvvuagittuq ferruginous rock formations (NMF)

$10(\sim 4.2-3.7 \mathrm{Ga})$, which were considered to be the oldest known traces of life on Earth (49).

These microfossils bares no close resemblance to any extant prokaryotes including R.sphaeroides $(R S)$; nevertheless, protoplasts of R.sphaeroides $(R S-P)$ exhibited uncanny morphological similarities to NMF microfossils (Fig. 8). All distinctive features of these microfossils like large spherical cells with one or two filamentous arms (Fig. 8 \& S76),

15 presence of an inner filamentous structure within these arms (TEM cross sections in Fig. 8C); spherical or filamentous outer membrane vesicles (OMV) being formed by blebbing of outer membrane (Fig. 8, S77 and Movie S9); were also observed in $R S-P$.

Like $E M-P$, during the last growth- stage $R S-P$ underwent lysis that led to formation of 20 membrane debris (fig. S78 \& S79). Two types of membrane debris were observed in $R S-P$ incubations - film-like (fig. S78) and filamentous (fig. S79). Such membrane debris formed by $R S-P$ bare close morphological resemblance to filamentous organic structures reported from Kitty’s Gap Chert (fig. S79) (50) and film-like structures reported from BGB (fig. S79) $(21,51)$. Like observed in $\mathrm{BGB}, R S-P$ formed biofilms with morphologically analogous rice grain-like cells (fig. S80). 


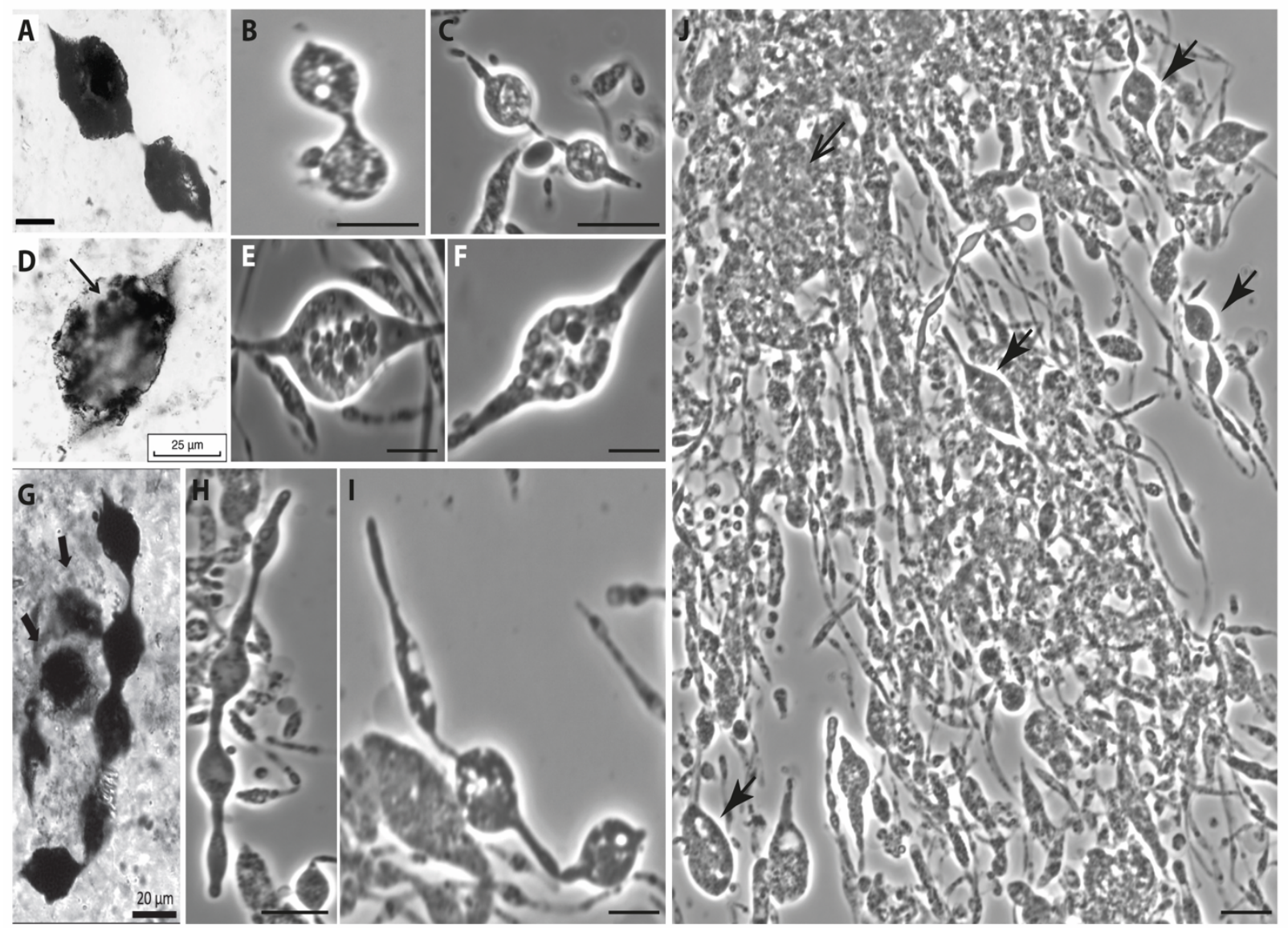

Fig 7. Morphological comparison of SPF lenticular microfossils with $R S-P$.

Images A, D\&G are lenticular microfossils reported from Pilbara region, WA (originally

5 published by Sugitani et al., 2007) (32). Images B, C, E, F, H, I \&K are images of 10-18 days old $R S-P$ cells. Images A-C shows lenticular WA microfossils and $R S-P$ cells in pairs, probably undergoing cell separation. D-F shows lenticular WA microfossils and $R S-P$ cells with overhangs probably formed by separation of cells from chains $(\mathrm{G} \& \mathrm{H})$ and spherical intracellular structures. Images G-I shows lenticular WA microfossils and $R S-P$ cells arranges as chains of lenticular cells. Image $\mathrm{J}$ shows wide filed image of $10-15$ days old $R S-P$ colony. Black arrows point to cells with internal reticulate structures. Scale bars: $5 \mu \mathrm{m}(\mathrm{B}, \mathrm{C}, \mathrm{E}, \mathrm{F}, \mathrm{H}$ $\& \mathrm{I})$ and $10 \mu \mathrm{m}(\mathrm{J})$. 


\section{Implications for taxonomy and ecophysiology of Archaean Eon microfossils}

Advances in both microscopic (FIB-SEM) and analytical (NanoSIMS) techniques over the past few decades have facilitated precise determination of chemical and isotopic compositions of microfossils $(11,52)$. Nevertheless, there is a considerable disagreement among researchers regarding the interpretation of this information (11). Decades of back-andforth arguments led to general consensus, that reconstructing the life cycles of Archaean Eon organisms, is considered the only way for understanding the nature of
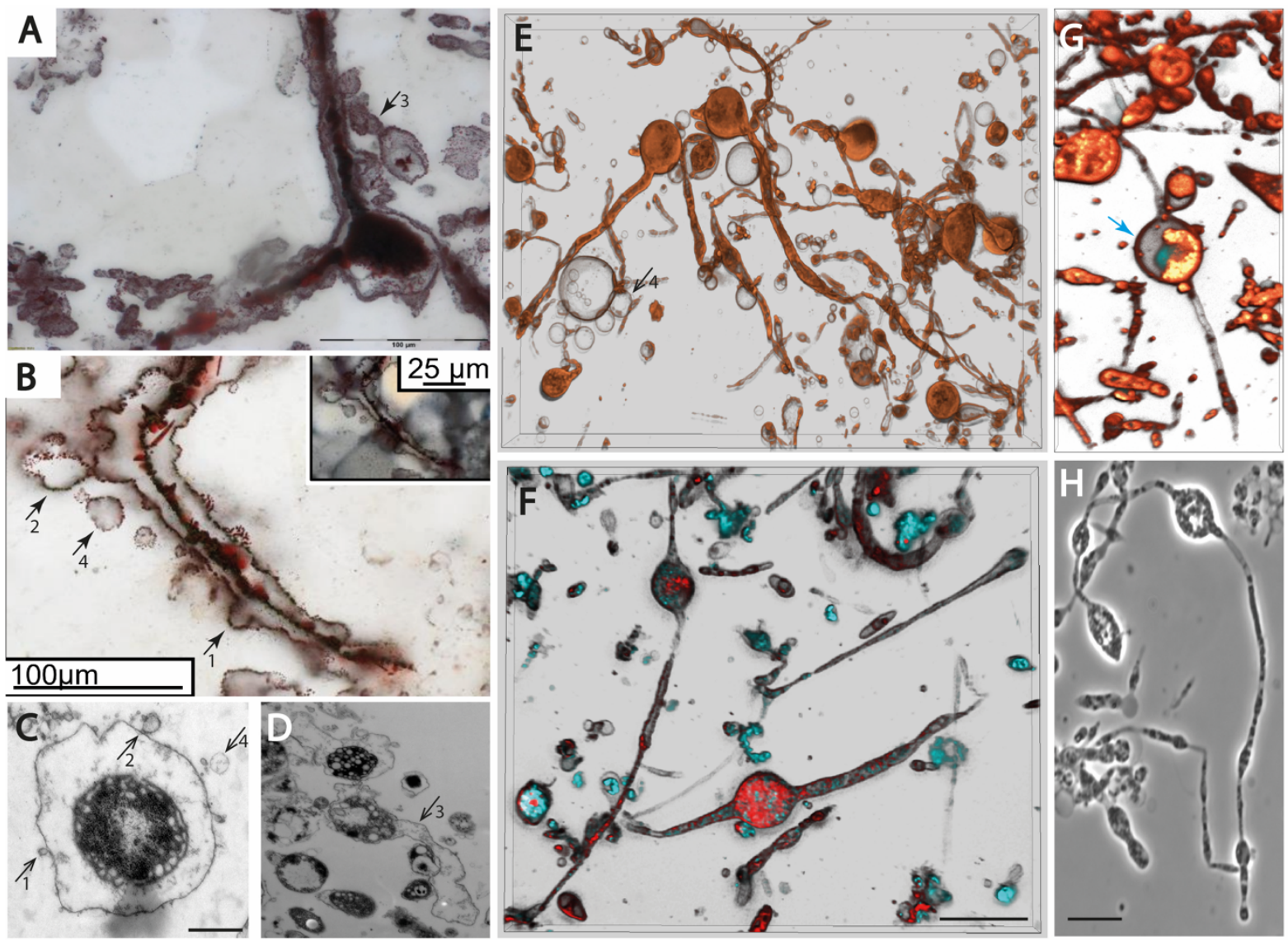

Fig 8. Morphological comparison of $R S-P$ with NMF.

A \& B are images of NMF (originally published by Dodd et al., 2017) (49). C-H are morphologically analogous $R S-P$ with one or two filamentous extensions. C\&D are the TEM cross sections of such filamentous cells exhibiting large periplasmic space (C), similar to 
NMF microfossils (B). Arrows in the images A-E points to the spherical (C) and filamentous (D) OMV's being formed by membrane blebbing. Numbers on arrows depicts sequential stages involved in formation of these vesicles. E-H are 3D-STED and phase-contrast images of $R S-P$ with one or two filamentous extensions, that were similar to NMF microfossils

5 (A\&B). Movie S9 show $R S-P$ with similar OMV's. Scale bars: $0.5 \mu \mathrm{m}(\mathrm{C} \& \mathrm{D})$ and $10 \mu \mathrm{m}(\mathrm{E}-$ $\mathrm{H})$.

these microfossils (13). To the best of our knowledge, ours is the first study to reproduce all known microfossil morphologies and their lifecycles from extant bacteria. In the following sections of this manuscript, we attempt to answer some long-standing questions like - Were these organic structures are of biological origin? How did microfossils reported from farflung sites like Western Australia and South Africa exhibited very similar morphologies? Are they or are they not Cyanobacteria? along with likely explanation behind their $\delta^{13} \mathrm{C}$-biomass values.

Biological origin of several organic structures was questioned by previous studies as morphologies of these structures resemble mineral aggregates formed by abiotic processes (9-12). Underlying argument for this proposition was that these structures bare greater morphological resemblance to inorganic mineral structures rather than extant microorganisms and lack true morphological analogues within extant prokaryotes. One of the most important criteria for establishing biogenicity of a microfossil is either to present a convincing morphological analogue among extant bacteria or to establish a biogenic process by which they are formed. The biogenicity of Swartkoppoie formation microfossils (fig. S31) was widely accepted among scientific community due to the discovery of spherical microfossil in different stages of their cell-division (6). To date, such a step-by-step biological process by 
which Archean Eon organic structures might have formed has never been presented, adding to the confusion over the nature of Archaean Eon organic structures. Below we present such sequential biological processes by which these organic structures are formed.

5 Among the microfossils in question, much of the criticism was devoted to Apex Chert microfossils (9). Presence of organic carbon only at the periphery of the cell; absence of internal cell constituents; random pattern in cell length and width (fig. S66\&S68); twisting (fig. S72-S74 \& S81) and branching (Fig. 9) of cells, which is inconsistent with morphologies of any known filamentous bacteria; presence of silicate minerals inside the filaments; were all argued as claims for their abiotic origin (11). Justifiably, such structures were never before observed in any living organism. Nevertheless, we observed all these morphological features in $R S-P$, suggesting these features were within the realm of possible bacterial morphologies. Here we also showed that cells could exhibit such morphologies in their protoplast state when exposed to environmental conditions, similar to the ones experienced by cells at the time of

15 their fossilisation (14) (discussed below). Several of the above highlighted features like presence of inorganic salts within the microfossils and inconsistencies in dimension of individual cells within a filament are not restricted to Apex chert microfossils (53). Such discrepancies were reported from several bona-fide microfossil from other sites (53). Regarding the presence of silicate minerals inside the cell, we argue that these inorganic minerals should have entered the cell during the formation of membrane vesicles, taking with them the inorganic minerals from the surroundings (fig. S82). Moreover, morphologies of Apex chert organic structures were also in continuity with the microfossil morphologies from other sites, all of which represent one of the growth stages of $R S-P$ or $E M-P$, further corroborating biological nature of these microfossils. 

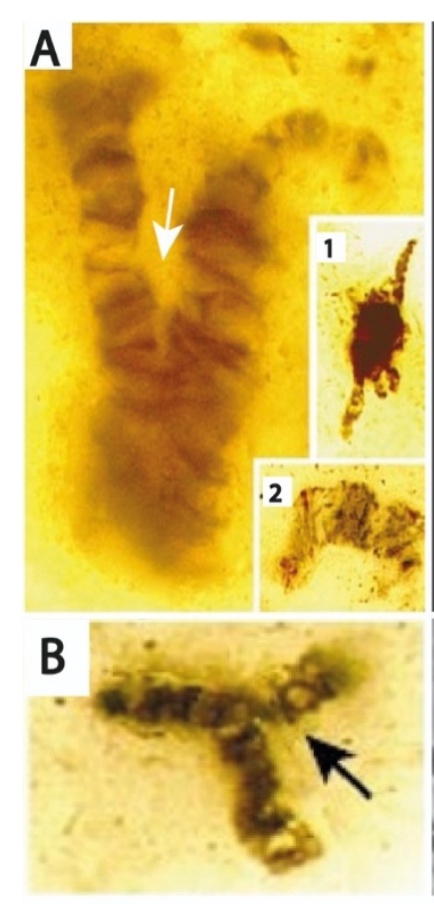
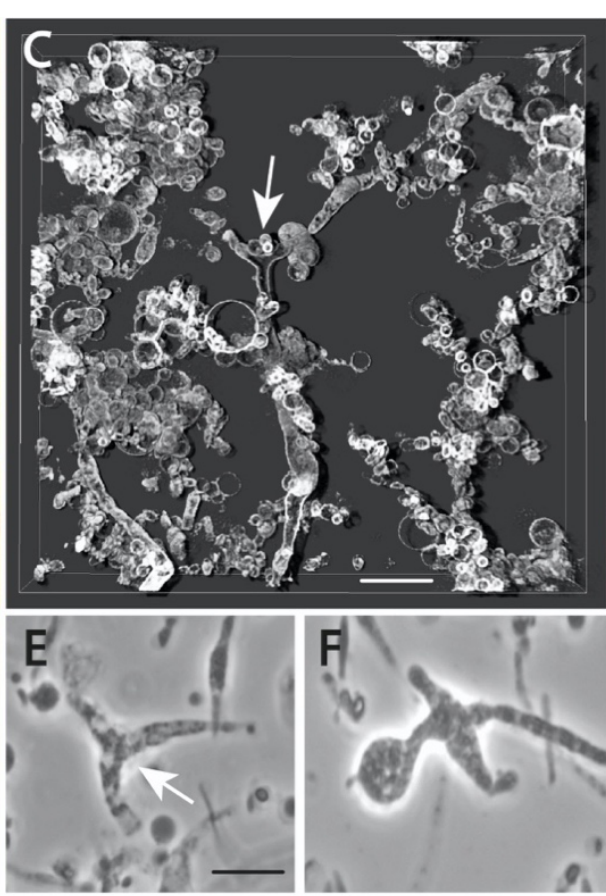
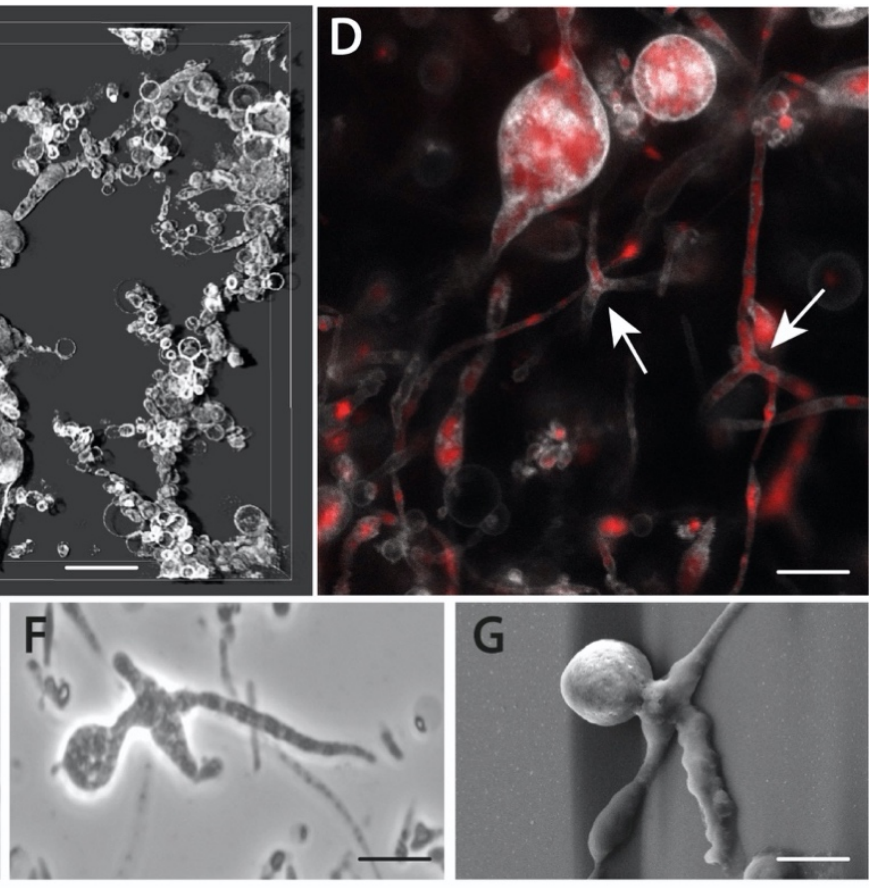

Fig 9. Comparison of filamentous $R S-P$ cells with Apex chert microfossils.

Image A \& B show microfossils reported from Apex chert, exhibiting branching (originally published by Brasier et al., 2002)(9). C-G are STED (C \& D), phase-contrast (E \& F) and

SEM (G) images of $R S-P$ cells exhibiting a similar branching pattern. Cells in image C\&D are stained with DNA stain PicoGreen (red) and membrane stain FM ${ }^{\mathrm{TM}} 5-95$ (white). Arrows in Images A-E points to the branching of filaments observed in both Apex chert microfossils and $R S$ - $P$. Images A1 shows a lenticular cell with filamentous overhangs, morphologically similar cell can be seen in image D. Scale bar: $5 \mu \mathrm{m}(\mathrm{C}-\mathrm{F})$ and $1 \mu \mathrm{m}(\mathrm{G})$.

Along with Apex chert organic structures, recent reports argue that elliptical and spherical organic structures (microfossils) reported from several Archaean rock formations like SPF (49), Dresser (10) and Moodies formations (12) are abiotic mineral aggregates, rather than fossilised Archaean Eon microorganisms. In-case of elliptical organic structures reported from SPF site, all distinctive morphological features, that were being argued as indications for their abiotic origin like presence of granular interiors (fig. S83-S86), lath like structures 
(fig. S84-S86) within the cell and clasts of organic carbon layer enclosing the cell (fig. S87), were very similar to the ones observed in $R S-P$. Like $R S-P$, granular interiors of lenticular organic structures could have formed by invagination followed by vesiculation of cell membrane (fig. S88). Clast of organic carbon enclosing elliptical organic structures reported

5 from both SPF and Moodies formations (fig. S97), could have formed by excess membrane debris, that was observed during the late-stationary growth phase of $R S-P$ (fig. S78). Such sequential steps involved in formation and morphological transformation of membrane debris is presented as Fig S89 to S94. In-brief, entanglement of long filamentous $R S-P$ cells led to the formation of large clumps of cells (Fig S89A-E \& S90-S92). Over time, cells deep within

10 the clumps fused with one another or underwent lysis (during the last growth stage) (Fig S89F-D \& S90-S92). Lysis of cells within the clumps led to formation of membrane debris. Over time, the amount of membrane debris gradually increased leading to the formation of continuous film engulfing lenticular $R S-P$ cells (fig. S91). Given the morphological similarity between $R S-P$ and clasts of organic carbon reported from Dresser (49) and Moodies

15 formations (12) (fig. S87), we presume these structures were also formed by a similar process.

Organic structures that were being argued as shreds of volcanic glass (10) could also have formed from membrane debris of $R S-P$ like Archaean cells (fig. S92-S94). Small spherical

20 granules that were bound to the linear strands of organic carbon could have been the intracellular granules attached to linear strands of membrane debris, like observed in $R S-P$ (fig. S93 \& S94). In support of our proposition, all the intermediary morphologies observed in the transformation of lenticular $R S-P$ cells into linear strands of organic carbon were reported from these microfossil sites (Fig. 2A in Wacey et al.,2018) (10). Over time the 25 above-mentioned membrane debris transformed into Pumice like structures reported from 
these microfossil sites (sequential steps shown in fig. S74, S95 \& S96). Based on these similarities, we propose that these structures most likely were fossil remnants of proto-Gramnegative or proto-Gram-positive bacteria (fig. S96), rather than mineral aggregates.

5 Together with the elliptical structures, spherical organic structures were reported from Dresser formation (10) containing hollow silica filled vacuoles and a thick discontinuous wall (fig. S97-S98). TEM images of these structures showed thick, porous cell-walls like structures filled with with quartz and pyrite (fig. S99). In most cases, these cell-walls are discontinuous structure with uneven thickness (fig. S98-S99). Interiors of these organic 10 structures were mostly devoid of organic carbon (fig. S97-S99). All these observations were in sharp contrast to any known living cells. Nevertheless, EM-P exhibited all these morphological features (fig. S97-S99). What were assumed to be hollow spherical cells resemble vacuoles of $E M-P$, with daughter cells (fig. S97-S98). Similarly, what was assumed to be a cell-wall most likely is the cytoplasm sandwiched between hollow cell vacuole and 15 cell-membrane (fig. S99). The sequential morphological transformation of EM-P leading to the formation of such structures was depicted in fig. S100. What was thought to be a discontinuous or cell wall of uneven thickness is the patches of leftover cytoplasm after its gradual transfer from parent to daughter cells (fig. S99 \& S100). In support of this presumption, daughter cells within these hollow structures and release of these daughter cells

20 by lysis of vesicle membrane can be seen among the Dresser formation organic structures (fig. S97). Similarly, organic structures reported that were being argued as volcanic glass also resemble morphologies of $E M-P$ (fig. S101). The structures exhibiting a wavy lamellar pattern are likely the membrane debris formed after lysis and release of daughter cells (fig. S102). This membrane debris underwent further morphological transformation leading to the 25 formation of laminated structures (Fig 3, 4 \& fig. S48-S61). Given these morphological 
similarities between Moodies, Dresser formation organic structures and $E M-P$, we hypothesise that these organic structures are the fossil remnants of EM-P like proto-Grampositive bacteria rather than mineral aggregates.

5 Morphological similarity between microfossils from far flung sites like Western Australia and southern Africa could be explained by similarity in the environmental conditions in both sites. This relation between morphology, reproductive process and environmental conditions was discussed extensively in our previous work $(17,18)$. Culture conditions we employed in our study are presumably similar to the environmental conditions faced by Archaean organisms from both these sites, at the time of their fossilisation. All sites from which microfossils were reported are shallow intertidal regions. Evidence for periodic evaporation and flooding with sea water was presented from both BGB and PIF sites $(5,47)$, indicating all microfossils experienced high salinities. Given the 1.5 to 2 times higher salinities of Achaean oceans (14), we presume the salinities of the sea water could be similar to the ones used in our experiments $(5-10 \% \mathrm{w} \backslash \mathrm{v})$. To the best of our knowledge, the exact salt composition of the Archaean Ocean has not been elucidated. Hence, in our experiments we used complex mixture of salts (DSS) as a proxy to reproduce these salinities. Salts like $\mathrm{Mg}^{+2}, \mathrm{Ca}^{+2}, \mathrm{Na}^{+}$and $\mathrm{K}^{+}$salts or their oxides were reported to be present and constitute $1-5 \%$ by weight in both Pilbara and BGB microfossil sites $(5,47)$. Moreover, these salts were shown to be closely associated with microfossils from Apex chert. The pattern of spatial distribution of these salts seems to resemble the special distribution pattern of organic carbon, possibly indicating chelation of these salts to cell membrane, which is in agreement with our observations (11). Presence of potassium phyllosilicates and $\mathrm{NaCl}$ crystals within lenticular microfossils (47) is also in agreement with our hypothesis that internal structures of the microfossils should have 
in microfossils, presence of salt crystals on the cell surface, within the membrane invaginations or cell-debris was often observed in $E M-P$ (fig. S82), also supporting our hypothesis.

$5 \quad R S-P$ and $E M-P$ when grown in the presence of 5-10\% w/v DSS exhibited complex morphologies and lifecycles involving substantial morphological transformations. Only inherent property of these organisms that influenced the morphology is the architecture of the cell membrane. No morphological overlap was observed between $E M-P$ and $R S-P$. Different morphologies observed within these two groups are interchangeable. They either represent

10 differences in their growth stages or environmental conditions. Based on this property we classify microfossils into proto-Gram-positive, cells having a single bilayer membrane and proto-Gram-negative, cells having a dual bilayer membrane. All reported Archean microfossils resemble one of $E M-P$ (Fig.1-4 \& fig. S1-S61) or $R S-P$ (Fig. 5-8 \& fig. S61S81) morphotypes. For example, all the filamentous and lenticular microfossils reported from

15 PIF, BGB and NMF sites, were likely remains of a proto-Gram-negative (like $R S-P$ ) bacteria fossilised at different growth stages. Similarly, we classify all the spherical microfossils of different sizes exhibiting internal compartmentalisation, in dyads or organised as strands of pearls as likely remains of a proto-Gram-positive (like $E M-P$ ) bacteria fossilised at different growth stages. What was assumed to be fossilised EPS (21), most likely was the membrane

20 debris produced by these organisms (Fig.4 \& fig. S38-S46). Our results suggest, unlike extant bacteria which evolved mechanisms to regulate their morphology and mediate cell division, these primitive Archaean organisms most likely were dependent on physicochemical forces of the environment to mediate these processes. This phenomenon could also explain the similarities in the microfossil morphologies reported from far-flung sites like BGB in South 25 Africa and PIF in Australia (3, 12). 
Regarding the taxonomy and physiology of these microfossils, the most important criteria for establishing biogenicity and taxonomic classification of microfossils has always been their morphology and carbon isotopic composition. Given the consistency of morphology with 5 phylogeny in extant bacteria (55), filamentous nature of microfossils $(1,19)$ and $\delta^{13} \mathrm{C}-\mathrm{MF}$ biomass values (56), arguably suggesting their autotrophic physiology; this led to annotating most of the above discussed microfossils as Cyanobacteria $(1,35)$. Justifiably, colony characteristics of microfossils like formation of multi-layered stromatolite like structures and mechanisms of reproduction observed in some of these microfossils were similar to

10 Cyanobacteria belonging to genus Pleurocapsa (57). But, more recent studies on microfossil morphologies $(\geq 10 \mathrm{~nm}$ resolution)(11) and genome analysis of extant Cyanobacteria were not in-tune with this claim $(58,59)$. For instance, Cyanobacteria have a cell-wall that is thicker than other Gram-negative bacteria (60). The cell-walls of both heterocysts and akinete spores are considerably thicker $(51,52)$. Neither indications of a thicker cell-wall nor the presence of internal structures consistent with the morphology of a heterocysts or akinete's were reported from PIF microfossils (11). The periphery of Apex chert microfossils is marked by $5 \mathrm{~nm}$ carbon layer, matching the thickness of a lipid bilayer like observed in $R S-P$, rather than a cell-wall (Fig. 10).

20 Analyses of cyanobacterial genomes also concluded that they first evolved in fresh-water habitats and then evolved mechanisms to colonize marine habitats (58). Given the high salinities of microfossil sites and Precambrian oceans (14), we do not assume that this happened long before the great oxidation event (62). Early cyanobacterial morphologies were also considered to be restricted to simpler unicellular cocci. The filamentous forms exhibiting cell differentiation and large spherical baeocyte forming morphotypes are not thought to have 
evolved until 2.5 Ga (59), contradicting the annotation of filamentous PIF microfossils as Cyanobacteria. Upon long-term incubation (30 months) EM-P cells got encrusted with salts from the culture media to form stromatolite like structures, resembling Cyanobacteria (fig. S103), microfossils from Kromberg formation (fig. S104), North Pole (fig. S105) and SPF

5 formation (fig. S106)(19-21). Based on uncanny morphological similarities between bacterial protoplasts from our study and Archaean microfossils, we propose that these microfossils are primitive cells yet to evolve a cell-wall rather than Cyanobacteria.

Discovery of microfossils in Archaean BIF's and $\delta^{13} \mathrm{C}$-biomass values, contributed to the 10 wider acceptance of the proposition that these microfossils were Cyanobacteria. Although, presence of isotopically lighter carbon of microfossil biomass in-comparison to surrounding rock carbonates suggests their biological nature. In our opinion, further interpretation of their physiology solely based on one time-point $\delta^{13} \mathrm{C}$-biomass is fraught with errors. Moreover, drawing parallels between $\delta^{13} \mathrm{C}$-biomass of extant bacteria belonging to a particular

15 physiological group and $3.8 \mathrm{Ga}$ microfossils, involves subscribing to the idea that both these organisms used the same physiological pathways with identical enzymes. Such assumptions are not in-tune either with the principles of Darwinian evolution or with the phylogenetic diversity and isotope discrimination properties of enzymes within a carbon fixation process (63-65). As an example, key enzyme of Calvin-Benson-Basham (CBB) cycle, RubisCO, was

20 known to have diversified into several phylogenetic classes over time $(63,64)$. These isoforms differ from each other not only in their carbon isotope fractionation values (66) but also in their substrate specificity (65), reaction kinetics (65), and even in their function (67, 68). Existence of different isoforms of RubisCO's suggests existence of a proto-RubisCO, an evolutionary ancestor to all known RubisCO and RubisCO like proteins. The structure,

25 function and isotope fractionation properties of such proto-RubisCO is presently unknown. 
Even in case of extant Cyanobacteria, whose C-isotope fractionation properties are well determined, their $\delta^{13} \mathrm{C}$-biomass values in natural environments are known to fluctuate between $-34.4 \%$ to $-5.9 \%(69)$, indicating $\delta^{13} \mathrm{C}$-biomass values are prone to exhibit huge

5 variations in natural environments. These reported values (-34.4\% to $-5.9 \%)$ overlap with other known C-fixation processes like methanogenesis, homoacetogenesis and methanotrophy (70-74), which further complicates the distinction between different physiological pathways.
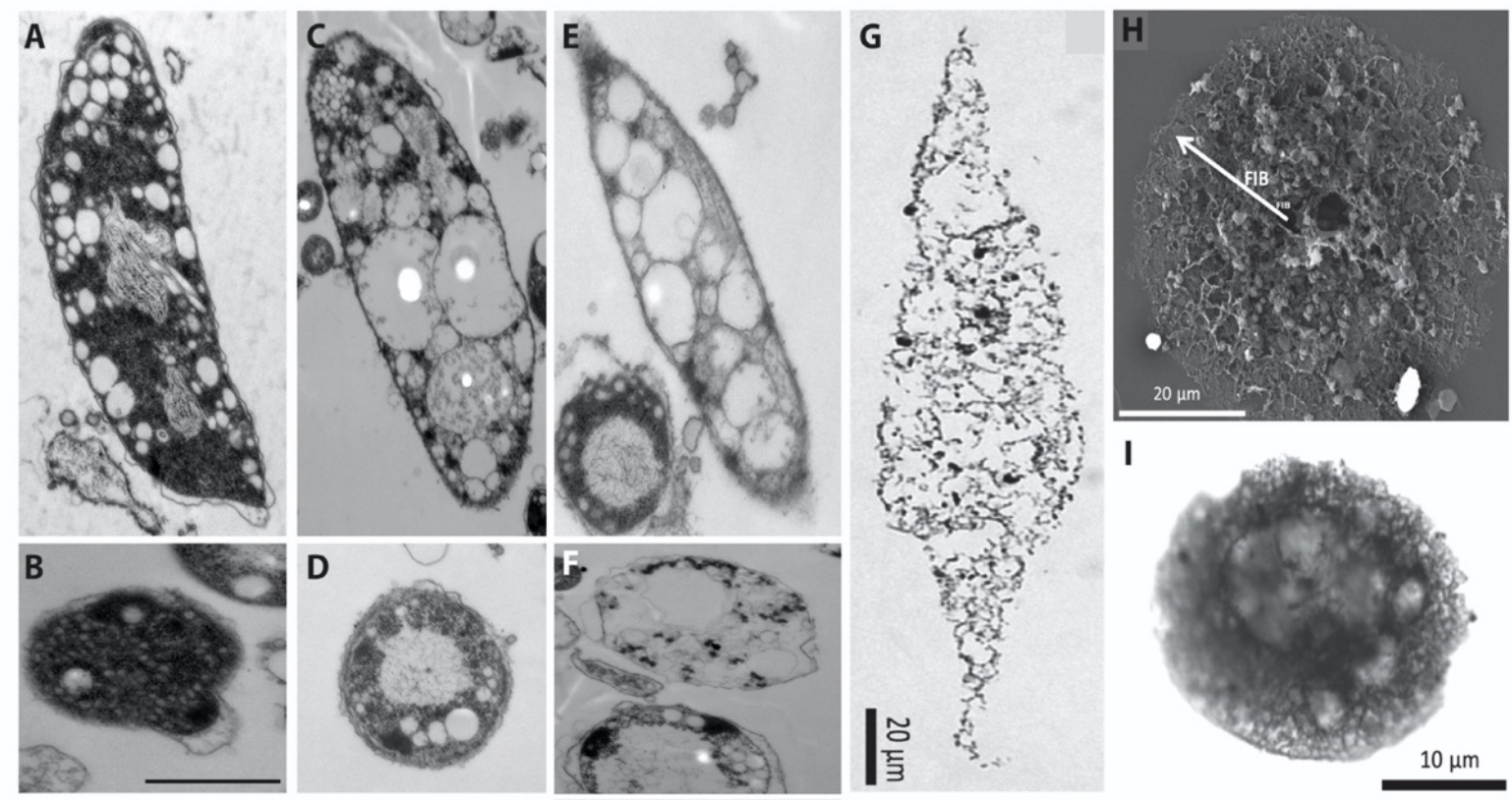

Fig 10. Morphological comparison of $R S-P$ with SPF microfossils.

Images A-F are horizontal (A-E) and lateral (B-F) cross section TEM images of $R S-P$. Images G-I are TEM (G) and FIB-SEM (H\&I) images of lenticular microfossils from Glodsworth locality (originally published by Sugitani et al., 2016) (75). Images A-E \& B-F shows sequential depletion of $R S-P$ 's cytoplasm and simultaneous increase in number of intracellular vesicles, leading to a reticulate appearance. Similar reticulate structures can be seen in microfossil images G\&I. Tiny spherical inclusions, similar to intracellular vesicles in $R S-P$ can be seen in microfossil image H. Scale bar (B): $1 \mu \mathrm{m}$. 
Lenticular microfossils with cytological differences were reported from Water fall region (28). Type-1 lenticular microfossils with uniformly distributed cytoplasm and $\delta^{13} \mathrm{C}$-biomass of $-27.4 \%$ resemble early growth stage of $R S-P$ cells (Fig. 6). Whereas Type-2 \& 3 lenticular 5 morphotypes with reticulate interiors, clots of organic carbon and lower $\delta^{13} \mathrm{C}$-biomass $(-30$ to $-32 \%$ and $-40 \%$ ) resemble late growth stage of $R S-P$ cells (Fig. 7). Such a gradual decrease in the cytoplasmic content together with an increase in intracellular membrane (reticulate) structures, was observed in $R S-P$ (Fig. $10 \&$ fig. S90). The gradual depletion in $\delta^{13} \mathrm{C}$-biomass values of microfossils could be due to the lower $\delta^{13} \mathrm{C}$-fatty acids compared to that of the $\delta^{13} \mathrm{C}$ 10 biomass (76). The lowest $\delta^{13} \mathrm{C}$-values of spherical organic carbon clots could be explained by differences in $\delta^{13} \mathrm{C}$-values of individual fatty acids. It was reported that unsaturated fatty acids were -4 to $-17 \%$ depleted in $\delta^{13} \mathrm{C}$-values compared to saturated fatty acids (76). When stained with dyes specific for lipids and liquid-disordered $\left(\mathrm{L}_{\mathrm{d}}-\right.$ mostly composed of unsaturated lipids) regions of the membrane, spherical internal vesicles were preferentially

15 stained with $\mathrm{L}_{d}$ stains (fig. S89). This indicate that these internal vesicles were largely composed of unsaturated fatty acids, which could explain lower $\delta^{13} \mathrm{C}$-values of these spherical clots. A similar pattern of differences was observed between $\delta^{13} \mathrm{C}$ values of saturated and unsaturated FA in $R S-P$ (Tab. S1 \& 2). Morphological comparison of $R S-P$ with lenticular microfossils also suggests most of the microfossil biomass could composed of fatty acids (Fig. 10). We presume, this variable nature of $\delta^{13} \mathrm{C}$-fatty acids further adds to the complexities in conclusively determining the C-incorporation pathways of these microfossils. Due to these uncertainties, we refrain from predicting either phylogeny or C-fixation pathways of these microfossils, solely based on their morphology or $\delta^{13} \mathrm{C}$-biomass of microfossils. Nevertheless, spatial distribution and isotopic composition of iron associated with microfossils seems to suggest their iron-oxidizing and iron-reducing physiology. 
Our assumption that these microfossils were proto-iron cycling bacteria rather than Cyanobacteria is supported by the fact that most (if not all) microfossils were discovered in BIF's and are closely associated with iron minerals (77). The oldest known microfossils

5 reported from Nuvvuagittuq ferruginous rock formations, are associated with hematite. Moreover in these microfossils hematite is associated with outer and inner membrane of the microfossils (Fig. 8, red spots on inner filament), suggesting that Fe(II)-oxidation took place in periplasmic space. This is in accordance with what is known from extant phototrophic $\mathrm{Fe}(\mathrm{II})$-oxidising bacteria (78). If $\mathrm{Fe}(\mathrm{II})$-oxidation was mediated by an abiotic process, with $\mathrm{O}_{2}$

10 produced by Cyanobacteria, we expect Fe(III)-hydroxides to be localised to cell surface, rather than in the periplasmic space. The pattern of Fe(III) distribution in several BIF's, like Dresser formation (10) resemble the morphologies observed in $R S-P$ (incidentally, a genus well studied for phototrophic Fe(II)-oxidation). Some Archaean BIF's were reported to have magnetite/hematite precipitated as granules, enclosed in a lenticular structure (79) - Granular 15 iron formations (fig. S108). These structures were morphologically similar to the ones observed in $R S-P$. Based on these similarities, we propose the following sequence of events that could have led to their formation - Oxidation of $\mathrm{Fe}(\mathrm{II})$ to Fe(III) could have happened in the periplasmic space (78) of lenticular microfossils, following this Fe(III) cation could have adsorbed to the anionic cell-membrane, this chelation could have led to the invagination and

20 formation of spherical intracellular vesicles with Fe(III)-mineral coating around them. This phenomenon of vesicle formation by electrostatic interaction between cations and phospholipid membranes is a well-studied phenomenon (80). The $\delta^{56} \mathrm{Fe}$ values of Archaean eon BIF's are also in agreement with anaerobic Fe(II)-oxidation processes and inconsistent with abiotic Fe(II)-oxidation coupled with oxygen produced by Cyanobacteria $(81,82)$, which is also in accordance with our hypothesis. Based on these observations we propose that 
these microfossils most likely are proto-iron oxidizing bacteria resembling $R S-P$ in their morphology rather than Cyanobacteria. Likewise, we propose the spherical microfossils reported from SPF, Moodies and Dresser formation, are proto iron reducing bacteria. This assumption is based on the fact that all spherical microfossils were discovered from pyrite 5 rich laminations (52).

Instead of annotating Archaean Eon microfossils to a particular phylogenetic group of extant bacteria, we hypothesise that these microfossils are protocells proposed by theory of chemical evolution (83). This theory proposed the existence of protocells, as an evolutionary

10 intermediate between abiotic chemical reactions happening on early Earth and evolution of prokaryotes. These cells were hypothesised to be primitive and devoid of all molecular biological processes regulating either their morphology or cell-division. Most of our current understanding of protocells and their mode of cell-division was largely either a result of studying lipid vesicles, termed bottom-up approach (84) or from studying cells whose genome was sequentially reduced to its bare minimum (85), termed top-down approach. Morphologies and mode of cell-division observed in $R S-P$ and $E M-P$ is in accordance with theories proposed by both top-down and bottom-up approaches (86). Moreover, morphologies of $E M-P$ and microfossils, very much resemble the simulated morphologies of protocells generated by numerical modelling approaches (87). As our hypothesis is in perfect

20 accordance with results from above-described approaches, we argue for reinterpretation of these microfossils as protocells (proto-Gram-negative \& proto-Gram-positive cells) and discourage use of microfossil morphology as a basis for systemic palaeontology.

To date, our understanding of early life on earth resulted from advances in several fields of 25 biology: palaeontology, which deals with morphology and isotopic signatures of microfossils; 
phylogeny, which addresses genomic changes that happened over time; and a bottom-up approach of studying lipid vesicles. However, these fields were seldom integrated with one other to form coherent conclusions. Here we provide a missing link connecting these studies. We propose that microfossils observed in Archaean BIFs were most likely liposome like

5 protocells, which had evolved mechanisms for energy conservation, but not for regulating cell morphology and replication. To the best of our knowledge, ours is the first study to provide paleontological evidence of the existence of liposome like protocells on Archaean Eon Earth.

\section{References and Notes:}

1. J. W. Schopf, Microfossils of the Early Archean Apex chert: new evidence of the antiquity of life. Science. 260, 640-646 (1993).

2. M. M. Walsh, D. R. Lowe, Filamentous microfossils from the 3,500-Myr-old Onverwacht Group, Barberton Mountain Land, South Africa. Nature. 314, 530 (1985).

3. J. W. Schopf, E. S. Barghoorn, Alga-like fossils from the early Precambrian of South Africa. Science. 156, 508-512 (1967).

20 4. D. Z. Oehler, M. M. Walsh, K. Sugitani, M.-C. Liu, C. H. House, Large and robust lenticular microorganisms on the young Earth. Precambrian Res. 296, 112-119 (2017).

5. M. W. Walsh, Microfossils and possible microfossils from the early archean onverwacht group, barberton mountain land, South Africa. Precambrian Res. 54, 271293 (1992). 
6. A. H. Knoll, E. S. Barghoorn, Archean microfossils showing cell division from the Swaziland System of South Africa. Science. 198, 396-398 (1977).

7. J. W. Schopf, K. Kitajima, M. J. Spicuzza, A. B. Kudryavtsev, J. W. Valley, SIMS analyses of the oldest known assemblage of microfossils document their taxoncorrelated carbon isotope compositions. Proc. Natl. Acad. Sci. 115, 53-58 (2018).

8. H. Gee, That's life? Nature. 416, 28 (2002).

9. M. D. Brasier, O. R. Green, A. P. Jephcoat, A. K. Kleppe, M. J. Van Kranendonk, J. F. Lindsay, A. Steele, N. V. Grassineau, Questioning the evidence for Earth's oldest fossils. Nature, 416, 76-81(2002).

10. D. Wacey, N. Noffke, M. Saunders, P. Guagliardo, D. M. Pyle, Volcanogenic PseudoFossils from the 3.48 Ga Dresser Formation, Pilbara, Western Australia. Astrobiology. 18, 539-555 (2018).

11. D. Wacey, M. Saunders, C. Kong, A. Brasier, M. Brasier, 3.46 Ga Apex chert 'microfossils' reinterpreted as mineral artefacts produced during phyllosilicate exfoliation. Gondwana Res. 36, 296-313 (2016).

12. I. Köhler, C. Heubeck, Microbial-mat-associated tephra of the Archean Moodies Group, Barberton Greenstone Belt (BGB), South Africa: Resemblance to potential biostructures and ecological implications. South African J. Geol. 122, 221-236 (2019).

13. K. Sugitani, K. Grey, T. Nagaoka, K. Mimura, M. R. Walter, Taxonomy and biogenicity of Archaean spheroidal microfossils (ca. 3.0 Ga) from the Mount Goldsworthy-Mount Grant area in the northeastern Pilbara Craton, Western Australia. Precambrian Res. 173, 50-59 (2009).

14. L. P. Knauth, Salinity history of the Earth's early ocean. Nature. 395, 554 (1998).

15. R. E. Blake, S. J. Chang, A. Lepland, Phosphate oxygen isotopic evidence for a temperate and biologically active Archaean ocean. Nature. 464, 1029-1032 (2010). 
16. D. C. Catling, K. J. Zahnle, The Archean atmosphere. Sci. Adv. 6 eaax1420 (2020).

17. D. Kanaparthi et al., https://www.biorxiv.org/content/10.1101/2021.11.25.470037v1.

18. D. Kanaparthi et al., https://www.biorxiv.org/content/10.1101/2021.11.25.470039v1.

19. K. Sugitani, K. Mimura, T. Nagaoka, K. Lepot, M. Takeuchi, Microfossil assemblage from the 3400 Ma Strelley Pool Formation in the Pilbara Craton, Western Australia: results form a new locality. Precambrian Res. 226, 59-74 (2013).

20. R. Buick, Microfossil Recognition in Archean Rocks: An Appraisal of Spheroids and Filaments from a 3500 M.Y. Old Chert-Barite Unit at North Pole, Western Australia. Palaios. 5, 441-459 (1990).

21. F. Westall, M. J. de Wit, J. Dann, S. van der Gaast, C. E. J. de Ronde, D. Gerneke, Early Archean fossil bacteria and biofilms in hydrothermally-influenced sediments from the Barberton greenstone belt, South Africa. Precambrian Res. 106, 93-116 (2001).

22. F. Delarue, F. Robert, S. Derenne, R. Tartèse, C. Jauvion, S. Bernard, S. Pont, A. Gonzalez-Cano, R. Duhamel, K. Sugitani, Out of rock: a new look at the morphological and geochemical preservation of microfossils from the 3.46 Gyr-old Strelley Pool Formation. Precambrian Res. 336, 105472 (2020).

23. G. J. Retallack, D. H. Krinsley, R. Fischer, J. J. Razink, K. A. Langworthy, Archean coastal-plain paleosols and life on land. Gondwana Res. 40, 1-20 (2016).

24. E. V. Barlow, M. J. Van Kranendonk, Snapshot of an early Paleoproterozoic ecosystem: Two diverse microfossil communities from the Turee Creek Group, Western Australia. Geobiology. 16, 449-475 (2018).

25. J. W. Schopf, B. M. Packer, Early Archean (3.3-billion to 3.5-billion-year-old) microfossils from Warrawoona Group, Australia. Science. 237, 70-73 (1987).

26. D. Wacey, M. R. Kilburn, M. Saunders, J. Cliff, M. D. Brasier, Microfossils of 
sulphur-metabolizing cells in 3.4-billion-year-old rocks of Western Australia. Nat. Geosci. 4, 698-702 (2011).

27. K. Sugitani, K. Mimura, M. Takeuchi, T. Yamaguchi, K. Suzuki, R. Senda, Y. Asahara, S. Wallis, M. J. Van Kranendonk, A Paleoarchean coastal hydrothermal field inhabited by diverse microbial communities: the Strelley Pool Formation, Pilbara Craton, Western Australia. Geobiology. 13, 522-545 (2015).

28. K. Lepot, K. H. Williford, T. Ushikubo, K. Sugitani, K. Mimura, M. J. Spicuzza, J. W. Valley, Texture-specific isotopic compositions in 3.4 Gyr old organic matter support selective preservation in cell-like structures. Geochim. Cosmochim. Acta. 112, 66-86 (2013).

29. J. Kazmierczak, W. Altermann, B. Kremer, S. Kempe, P. G. Eriksson, Mass occurrence of benthic coccoid cyanobacteria and their role in the production of Neoarchean carbonates of South Africa. Precambrian Res. 173, 79-92 (2009).

30. M. M. Tice, Environmental controls on photosynthetic microbial mat distribution and morphogenesis on a 3.42 Ga clastic-starved platform. Astrobiology. 9, 989-1000, (2009).

31. J. W. Schopf, A. B. Kudryavtsev, J. T. Osterhout, K. H. Williford, K. Kitajima, J. W. Valley, K. Sugitani, An anaerobic $~ 3400$ Ma shallow-water microbial consortium: Presumptive evidence of Earth's Paleoarchean anoxic atmosphere. Precambrian Res. 299,309-318 (2017).

32. K. Sugitani, K. Grey, A. Allwood, T. Nagaoka, K. Mimura, M. Minami, C. P. Marshall, M. J. Van Kranendonk, M. R. Walter, Diverse microstructures from Archaean chert from the Mount Goldsworthy-Mount Grant area, Pilbara Craton, Western Australia: microfossils, dubiofossils, or pseudofossils? Precambrian Res. 158, 228-262 (2007). 
33. E. J. Javaux, C. P. Marshall, A. Bekker, Organic-walled microfossils in 3.2-billionyear-old shallow-marine siliciclastic deposits. Nature. 463, 934-938 (2010).

34. L. J. Duck, M. Glikson, S. D. Golding, R. E. Webb, Microbial remains and other carbonaceous forms from the 3.24 Ga Sulphur Springs black smoker deposit, Western Australia. Precambrian Res. 154, 205-220 (2007).

35. J. Kaźmierczak, B. Kremer, Pattern of cell division in 3.4 Ga-old microbes from South Africa. Precambrian Res. 331, 105357 (2019).

36. Y. Ueno, Y. Isozaki, K. J. McNamara, Coccoid-like microstructures in a 3.0 Ga chert from Western Australia. Int. Geol. Rev. 48, 78-88 (2006).

37. K. Hickman-Lewis, F. Westall, B. Cavalazzi, Traces of early life from Barberton Green stone belt, in Earth's Oldest Rocks, pages 1029-1058 (2019).

38. D. Wacey, M. Saunders, J. Cliff, M. R. Kilburn, C. Kong, M. E. Barley, M. D. Brasier, Geochemistry and nano-structure of a putative 3240 million-year-old black smoker biota, Sulphur Springs Group, Western Australia. Precambrian Res. 249, 1-12 (2014).

39. M. M. Tice, D. R. Lowe, The origin of carbonaceous matter in pre-3.0 Ga greenstone terrains: A review and new evidence from the 3.42 Ga Buck Reef Chert. Earth-Science Rev. 76, 259-300 (2006).

40. M. M. Tice, D. R. Lowe, Photosynthetic microbial mats in the 3,416-Myr-old ocean. Nature. 431, 549-552 (2004).

41. M. Homann, C. Heubeck, A. Airo, M. M. Tice, Morphological adaptations of 3.22 Gaold tufted microbial mats to Archean coastal habitats (Moodies Group, Barberton Greenstone Belt, South Africa). Precambrian Res. 226, 47-64 (2015).

42. F. Westall, C. E. J. De Ronde, G. Southam, N. Grassineau, M. Colas, C. Cockell, H. Lammer, Implications of a 3.472-3.333 Gyr-old subaerial microbial mat from the 
early Earth, Philosophical Transactions of the Royal Society B: Biological Sciences 361, 1857-1875 (2006).

43. M. D. Brasier, O. R. Green, J. F. Lindsay, N. McLoughlin, A. Steele, C. Stoakes, Critical testing of Earth's oldest putative fossil assemblage from the $\sim 3.5 \mathrm{Ga}$ Apex chert, Chinaman Creek, Western Australia. Precambrian Res. 140, 55-102 (2005).

44. K. Hickman-Lewis, R. J. Garwood, M. D. Brasier, T. Goral, H. Jiang, N. McLoughlin, D. Wacey, Carbonaceous microstructures from sedimentary laminated chert within the 3.46 Ga Apex Basalt, Chinaman Creek locality, Pilbara, Western Australia. Precambrian Res. 278, 161-178 (2016).

45. M. Homann, P. Sansjofre, M. Van Zuilen, C. Heubeck, J. Gong, B. Killingsworth, I. S. Foster, A. Airo, M. J. Van Kranendonk, M. Ader, S. V. Lalonde, Microbial life and biogeochemical cycling on land 3,220 million years ago. Nat. Geosci. 11, 665-671 (2018).

46. Y. Ueno, Early Archean (ca. 3.5 Ga) microfossils and ${ }^{\wedge}<13>$ C-depleted carbonaceous matter in the North Pole area, Western Australia: Field occurrence and geochemistry. Geochemistry Orig. Life, 203-236 (2001).

47. J. Alleon, S. Bernard, C. Le Guillou, O. Beyssac, K. Sugitani, F. Robert, Chemical nature of the 3.4 Ga Strelley Pool microfossils. Geochemical Perspect. Lett. 7, 37-42 (2018).

48. B. Rasmusssn, Filamentous microfossils in a 3,235-million-year-old volcanogenic massive sulphide deposit. Nature. 405, 676-679 (2000).

49. M. S. Dodd, D. Papineau, T. Grenne, J. F. Slack, M. Rittner, F. Pirajno, J. O’Neil, C. T. S. Little, Evidence for early life in Earth's oldest hydrothermal vent precipitates. Nature. 543, 60-64 (2017).

25 50. F. Westall, S. T. De Vries, W. Nijman, V. Rouchon, B. Orberger, V. Pearson, J. 
Watson, A. Verchovsky, I. Wright, J. N. Rouzaud, D. Marchesini, A. Severine, The 3.466 Ga 'Kitty's Gap Chert,' an early Archean microbial ecosystem. in Processes on early Earth (2006).

51. K. Hickman-Lewis, B. Cavalazzi, F. Foucher, F. Westall, Most ancient evidence for life in the Barberton greenstone belt: Microbial mats and biofabrics of the $\sim 3.47 \mathrm{Ga}$ Middle Marker horizon. Precambrian Res. 312, 45-67 (2018).

52. D. Wacey, M. Saunders, C. Kong, Remarkably preserved tephra from the $3430 \mathrm{Ma}$ Strelley Pool Formation, Western Australia: Implications for the interpretation of Precambrian microfossils. Earth Planet. Sci. Lett. 487, 33-43 (2018).

53. K. Lepot, A. Addad, A. H. Knoll, J. Wang, D. Troadec, A. Béché, E. J. Javaux, Iron minerals within specific microfossil morphospecies of the $1.88 \mathrm{Ga}$ Gunflint Formation. Nat. Commun. 8, 14890 (2017).

54. K. Sugitani, K. Mimura, M. Takeuchi, K. Lepot, S. Ito, E. J. Javaux, Early evolution of large micro-organisms with cytological complexity revealed by microanalyses of 3.4 Ga organic-walled microfossils. Geobiology. 13, 507-521 (2015).

55. J. L. Siefert, G. E. Fox, Phylogenetic mapping of bacterial morphology. Microbiology. 144, 2803-2808 (1998).

56. J. W. Schopf, A. B. Kudryavtsev, Biogenicity of Earth's earliest fossils: a resolution of the controversy. Gondwana Res. 22, 761-771 (2012).

20 57. J. B. Waterbury, R. Y. Stanier, Patterns of growth and development in pleurocapsalean cyanobacteria. Microbiol. Rev. 42, 2 (1978).

58. P. Sánchez-Baracaldo, J. A. Raven, D. Pisani, A. H. Knoll, Early photosynthetic eukaryotes inhabited low-salinity habitats. Proc. Natl. Acad. Sci., 114, E7737-E7745 (2017).

25 59. J. C. Uyeda, L. J. Harmon, C. E. Blank, A comprehensive study of cyanobacterial 
morphological and ecological evolutionary dynamics through deep geologic time. PLoS One. 11, e0162539 (2016).

60. D. G. ADAMS, P. S. DUGGAN, Tansley Review No. 107. Heterocyst and akinete differentiation in cyanobacteria. New Phytol. 144, 3-33 (1999).

5 61. S. P. Singh, B. L. Montgomery, Determining cell shape: adaptive regulation of cyanobacterial cellular differentiation and morphology. Trends Microbiol. 19, 278-285 (2011).

62. A. D. Anbar, A. H. Knoll, Proterozoic ocean chemistry and evolution: a bioinorganic bridge? Science. 297, 1137-1142 (2002).

10 63. F. R. Tabita, T. E. Hanson, H. Li, S. Satagopan, J. Singh, S. Chan, Function, structure, and evolution of the RubisCO-like proteins and their RubisCO homologs. Microbiol. Mol. Biol. Rev. 71, 576-599 (2007).

64. F. R. Tabita, T. E. Hanson, S. Satagopan, B. H. Witte, N. E. Kreel, Phylogenetic and evolutionary relationships of RubisCO and the RubisCO-like proteins and the functional lessons provided by diverse molecular forms. Philos. Trans. R. Soc. Lond. B. Biol. Sci. 363, 2629-2640 (2008).

65. G. G. B. Tcherkez, G. D. Farquhar, T. J. Andrews, Despite slow catalysis and confused substrate specificity, all ribulose bisphosphate carboxylases may be nearly perfectly optimized. Proc. Natl. Acad. Sci. 103, 7246-7251 (2006).

20 66. G. D. Farquhar, J. R. Ehleringer, K. T. Hubick, Carbon isotope discrimination and photosynthesis. Annu. Rev. Plant Biol. 40, 503-537 (1989).

67. H. Ashida, Y. Saito, C. Kojima, K. Kobayashi, N. Ogasawara, A. Yokota, A functional link between RuBisCO-like protein of Bacillus and photosynthetic RuBisCO. Science. 302, 286-290 (2003).

25 68. T. Kono, S. Mehrotra, C. Endo, N. Kizu, M. Matusda, H. Kimura, E. Mizohata, T. 
Inoue, T. Hasunuma, A. Yokota, A RuBisCO-mediated carbon metabolic pathway in methanogenic archaea. Nat. Commun. 8, 14007 (2017).

69. K. Vuorio, M. Meili, J. Sarvala, Taxon-specific variation in the stable isotopic signatures ( $\delta 13 \mathrm{C}$ and $\delta 15 \mathrm{~N}$ ) of lake phytoplankton. Freshw. Biol. 51, 807-822 (2006).

5 70. H. Penning, C. M. Plugge, P. E. Galand, R. Conrad, Variation of carbon isotope fractionation in hydrogenotrophic methanogenic microbial cultures and environmental samples at different energy status. Glob. Chang. Biol. 11, 2103-2113 (2005).

71. D. Goevert, R. Conrad, Effect of Substrate Concentration on Carbon Isotope Fractionation during Acetoclastic Methanogenesis by Methanosarcina barkeri and M. acetivorans and in Rice Field Soil. Appl. Environ. Microbiol. 75, 2605-2612 (2009).

72. L. L. Jahnke, R. E. Summons, J. M. Hope, D. J. Des Marais, Carbon isotopic fractionation in lipids from methanotrophic bacteria II: The effects of physiology and environmental parameters on the biosynthesis and isotopic signatures of biomarkers. Geochim. Cosmochim. Acta. 63, 79-93 (1999).

73. R. D. Guy, M. L. Fogel, J. A. Berry, Photosynthetic Fractionation of the Stable Isotopes of Oxygen and Carbon. Plant Physiol. 101, 37-47 (1993).

74. J. A. Raven, A. M. Johnston, J. E. Kübler, R. Korb, S. G. McInroy, L. L. Handley, C. M. Scrimgeour, D. I. Walker, J. Beardall, M. Vanderklift, S. Fredriksen, K. H. Dunton, Mechanistic interpretation of carbon isotope discrimination by marine macroalgae and seagrasses. Funct. Plant Biol. 29, 355-378 (2002).

75. K. Sugitani, K. Mimura, M. Takeuchi, K. Lepot, S. Ito, E. J. Javaux, Early evolution of large micro-organisms with cytological complexity revealed by microanalyses of 3.4 Ga organic-walled microfossils. Geobiology. 13, 507-521 (2015).

76. K. L. Londry, L. L. Jahnke, D. J. Des Marais, Stable Carbon Isotope Ratios of Lipid Biomarkers of Sulfate-Reducing Bacteria. Appl. Environ. Microbiol. 70, 745-751 
(2004).

77. J. W. Schopf, Fossil record of cyanobacteria, in Ecology of cyanobacteria II (Springer, 2012), pp. 15-36.

78. Y. Jiao, D. K. Newman, The pio operon is essential for phototrophic Fe (II) oxidation in Rhodopseudomonas palustris TIE-1. J. Bacteriol. 189, 1765-1773 (2007).

79. M. S. Dodd, D. Papineau, Z. She, M. L. Fogel, S. Nederbragt, F. Pirajno, Organic remains in late Palaeoproterozoic granular iron formations and implications for the origin of granules. Precambrian Res. 310, 133-152 (2018).

80. A. Reddy, E. V Caler, N. W. Andrews, Plasma membrane repair is mediated by Ca2+regulated exocytosis of lysosomes. Cell. 106, 157-169 (2001).

81. N. Dauphas, M. Van Zuilen, M. Wadhwa, A. M. Davis, B. Marty, P. E. Janney, Clues from Fe isotope variations on the origin of early Archean BIFs from Greenland. Science. 306, 2077-2080 (2004).

82. N. Planavsky, O. Rouxel, A. Bekker, R. Shapiro, P. Fralick, A. Knudsen, Ironoxidizing microbial ecosystems thrived in late Paleoproterozoic redox-stratified oceans. Earth Planet. Sci. Lett. 286, 230-242 (2009).

83. Oparin, A. I. Chemistry and the Origin of Life. R. Inst. Chem. Rev., 2, 1-12 (1969).

84. I. Budin, J. W. Szostak, Physical effects underlying the transition from primitive to modern cell membranes. Proc. Natl. Acad. Sci. 108, 5249-5254 (2011).

20 85. C. A. Hutchison, R. Y. Chuang, V. N. Noskov, N. Assad-Garcia, T. J. Deerinck, M. H. Ellisman, J. Gill, K. Kannan, B. J. Karas, L. Ma, J. F. Pelletier, Z. Q. Qi, R. A. Richter, E. A. Strychalski, L. Sun, Y. Suzuki, B. Tsvetanova, K. S. Wise, H. O. Smith, J. I. Glass, C. Merryman, D. G. Gibson, J. C. Venter, Design and synthesis of a minimal bacterial genome. Science. 351, 6253 (2016).

25 86. T. F. Zhu, J. W. Szostak, Coupled growth and division of model protocell membranes. 
J. Am. Chem. Soc. 131, 5705-5713 (2009).

87. T. Ruiz-Herrero, T. G. Fai, L. Mahadevan, Dynamics of growth and form in prebiotic vesicles. Phys. rev. lett. 123, 031802 (2019).

Acknowledgments: We gratefully acknowledge Ralf Conrad for his input throughout the work. We would also like to thank Diane Newman for insightful discussion. We would like to thank Gabriella Berthal for excellent technical support, members of ALMF, EMBL and rest of Ecological microbiology lab for their support throughout the work.

Author contributions: DK conceived the work with input from TL. DK performed laboratory experiments. AK \& TB did SEM and TEM imaging. DK \& ML did confocal imaging. DK coordinated work between the authors. DK wrote the manuscript with input from TL, BZ, ML, AK, \& TB. This research was funded by the European Research Council 15 (ERC), grant agreement 616644 (POLLOX) to TL. 